\title{
EFFECTS OF IMMIGRATION ON LABOUR MARKETS AND GOVERNMENT BUDGETS - AN OVERVIEW -
}

\author{
WILLI LEIBFRITZ \\ PAUL O'BRIEN \\ JEAN-CHRISTOPHE DUMONT
}

CESIFO WORKING PAPER NO. 874

CATEgORY 4: LABOUR MARKETS

FEBRUARY 2003

\footnotetext{
An electronic version of the paper may be downloaded

- from the SSRN website: www.SSRN.com

- from the CESifo website: www.CESifo.de
} 


\title{
EFFECTS OF IMMIGRATION ON LABOUR MARKETS AND GOVERNMENT BUDGETS - AN OVERVIEW
}

\begin{abstract}
The paper provides an overview on recent trends of immigration in OECD countries and on the possible effects of immigration on labour markets and government budgets. It also discusses migration policies from an economic point of view. By bringing together a bulk of international literature on labour market and fiscal effects of migration in a systematic way it provides a framework for assessing the economic effects of migration and improving the knowledge base for migration policies.
\end{abstract}

Keywords: migration, labour markets, fiscal effects of migration.

JEL Code: H00, J00.

Willi Leibfritz

OECD Economics Department

2 rue André-Pascal

75775 Paris Cedex 16

France

willi.leibfritz@oecd.org
Paul O'Brien

OECD Economics Department

2 rue André-Pascal

75775 Paris Cedex 16

France

Jean-Christophe Dumont

OECD Directorate for Education, Employment,

Labour and Social Affairs

2 rue André-Pascal

75775 Paris Cedex 16

France 


\section{By Willi Leibfritz, Paul O'Brien and Jean-Christophe Dumont ${ }^{1}$}

\section{Introduction}

Migration has been an important phenomenon in many OECD countries, while in others it has potentially or actually become so. Some countries have traditionally been important net sources of emigrants, others have been destination countries, while a number have changed from the first to the second group. The movement of people from one country to another clearly has a wide range of economic effects. Because of the diversity of migration patterns, simple models cannot capture the full picture, and tend to be focused on particular aspects of the problem; but they can suggest the main lines that need to be investigated. The main economic effects of immigration (or emigration), are likely to be felt in the labour market and on public finance. Depending on the age and skill structure of the migrants, there will be changes in populations and labour supply, which will affect employment, wages and output. Migrants pay taxes and may benefit from public expenditure, to a degree, which again depends very much on the kind of migrant concerned. Since migration flows are very varied (economic, refugee, family, temporary, return etc., are among the frequently used -- and overlapping -- categories employed to classify migration), there can be no simple answer as to what the precise effects are; careful empirical work is needed. Since migration affects the demographic structure of the population, including the age structure and fertility, its effects are likely to be spread through time.

This paper is intended as an overview of these issues, bringing together some existing literature rather than presenting new results. ${ }^{2}$ After a brief look at the economic theory of migration (Section 2), it outlines recent developments of migration in OECD countries and the potential impact of EU enlargement on migration in Europe (Section 3). It then reviews the literature on the effects of immigration on labour markets (Section 4) and government budgets (Section 5). It concludes by discussing how economic policy may affect, or be affected by, the economic impacts of immigration (Section 6).

\section{Why do people migrate?}

The economic theory of migration starts from the assumption that (potential) migrants attempt to increase (or maximise) their utility over their remaining lifetime (Sinn et al., 2001). This implies a focus on consumption (private and public) and other factors which affect utility (such as the cultural and social environment, the climate etc.) and implies a comparison of (expected) conditions in a potential host country with those in the country of origin. Important determining factors will be income from labour, wealth and transfers. The economic and psychic costs of migrating, along with the costs of acquiring information on which to base the migration decision, intervene both to prevent any kind of recognisable

1. Major contributions were made by Jean-Pierre Garson. The authors are economists in the OECD Departments of Economics (Leibfritz, O'Brien) and Labour and Social Affairs (Dumont). This paper is based on joint work from these departments but the views expressed in this paper are those of the authors and do not necessarily represent those of the OECD. The authors are also grateful to Jorgen Elmeskov, Mike Feiner and Ann Vourc'h and John Martin for their comments on an earlier draft.

2. Analysis of the economic impact of migration in a number of countries will form part of forthcoming OECD Economic Surveys of these countries in the years 2003-5. 
equilibrium emerging and to ensure that historical accident plays a large part in observed migration behaviour. Furthermore, migration is often a family or even a community decision, migrants often quoting "a better future for my children" as a reason for moving, rendering an individualistic focus inadequate for a complete description and widening the list of relevant factors to such things as educational and healthcare systems.

Nevertheless, some regularities predicted by simplistic economic theory can be observed in migration patterns. As in Hicks (1932), often a point of departure for studies on migration decisions, wage differentials can be seen to be an importance influence on flows of migrants. Anecdotes also suggest that although information circulates imperfectly, it does circulate - the price asked by "people smugglers" fluctuates as a function of, among other things, the probability of a successful outcome for the migrant.

As income levels and employment opportunities are affected by general economic conditions including foreign trade restrictions or liberalisation, trade policy can in principle indirectly affect the decision to migrate. On the basis of earlier work by Heckscher and Ohlin, Mundell (1957) suggested that an increase in trade impediments stimulates movements of capital and labour while restricting factor mobility would stimulate trade. This hypothesis is based on the assumption that both trade and factor mobility tend to equalise commodity prices and factor prices (Factor Price Equalisation Hypothesis). An assumption that this is true is behind many estimates of the effect of past migrations on relative wages in the new and old worlds. ${ }^{3}$

While some empirical studies have supported the Factor Price Equalisation Hypothesis others have not. More recently Straubhaar (1988), Molle (1994) analysed the Intra-EC-trade (on a growing trend from 1958 to 1980) and the Intra-EC-migration flows (which was decreasing during the same period) and concluded that movements of goods and capital have been largely substitutes for movements of labour. Faini and Venturini (1993) also find evidence for substitution effects and suggest that more liberal trade policies in industrialised countries may reduce migration pressures. Others argue that trade liberalisation by itself may have no significant effect on migration but if accompanied in developing countries by other growthenhancing policies (such as investment in infrastructure and human capital) the propensity to emigrate could be reduced (Cogneau, Dumont and Izzo, 1998). Mouhoud (1998) also suggests that free trade by itself does not constitute a substitute for labour mobility. Richards (1994) analysing the situation in Latin America and south-east Asia and Cogneau and Tapinos (1995) taking the example of Morocco show that trade and migration are in fact complements, not substitutes; the reason being that when countries develop, the number of people who can afford to migrate increases (see also Schiff (1994)). Hence during the first phase of development, emigration may increase rather than diminish and only later after a higher standard of living has been reached to decline again and migrants may return, suggesting that migration and trade may be complementary in the short run and substitutable in the long run.

Hatton and Williamson (2002) identify four economic and demographic fundamentals which have driven migration over the past 150 years: gaps between rich high-wage countries and poor low-wage countries; poverty constraints which hinders migration in very poor sending countries (explaining why emigration in these countries first increases as a result of higher incomes which reduce the poverty constraint); the size of the young adult share in sending and receiving country populations; and the foreign-born migrant stock from the sending countries currently residing in the receiving country (network effects). Besides these economic factors migration policies also play an important (and often a decisive) role. For example, once the era of unrestricted migration to North America ended (this happened gradually, but was definitive after

3. See Hatton and Williamson (1998) for a wide-ranging discussion of some of the great migration movements of the $19^{\text {th }}$ and $20^{\text {th }}$ century, identifying many of the economic, demographic and political influences at work, as well as presenting estimates of the impact of migrations on relative wages based on standard neo-classical assumptions. 
a series of Immigration Acts between 1917 and 1924) the ebbs and flows of migration into the United States owed as much to policy changes as to variations in economic conditions, though these continue to play a role in migration pressures facing the US. Also migration within Europe has been attributed to different economic conditions between southern and western Europe and to liberalisation policies in the context of EU enlargement (see below).

\section{Trends and structure of migration ${ }^{4}$}

Over the past decades migration trends have differed across OECD countries and over time (Figure 1 and Table 1): The 1980s were characterised by an increase in immigration flows in most OECD countries. However, this rising trend did not persist through the 1990s in all major OECD areas. In Europe a substantial decline in the number of net entries was evident after a peak in 1992-1993, which was associated with the fall of the "iron curtain" and a number of wars and ethnic conflicts. The downturn continued until 1997-98, after which immigration started to rise again. The future EU enlargement could lead to further inflows from Central and Eastern European countries to Western European countries but there are different views about the likely size of this effect (see below). In the United States, net immigration increased steadily between the mid-1970s and the mid-1990s. In recent years, however, migration flows seem to have stabilised. In the other "traditional immigration countries", Canada and Australia, immigration also increased during the 1990s but less than in the United States and in Europe.

Figure 1. Net migration in major OECD areas ${ }^{1}$

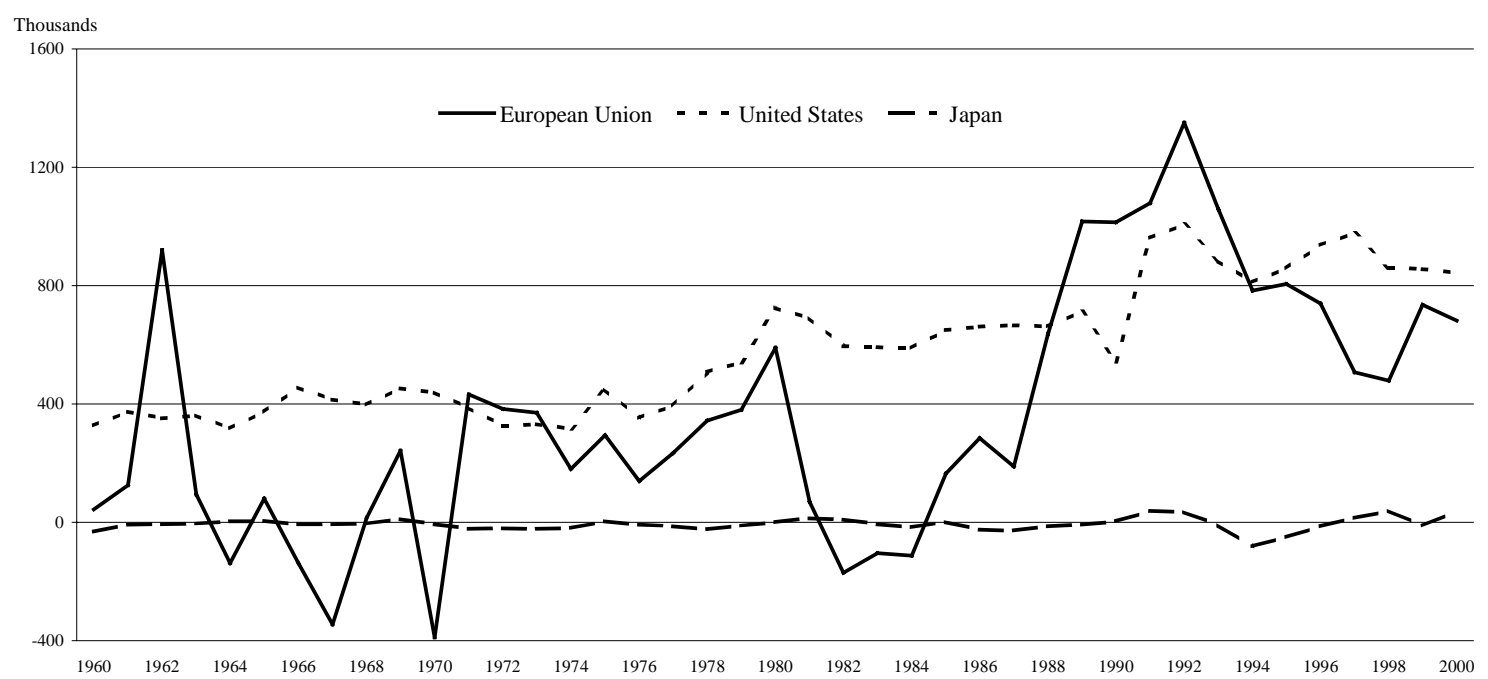

1. Net migration is measured as the difference between the total population on 1 January and 31 December for a given calendar year, minus the difference between births and deaths.

Source: OECD Labour Force Statistics.

4. This section draws from Part 1 of OECD (2001a) Trends in International Migration. Data on migration flows refer to legal flows, unless otherwise indicated. 
Table 1. Foreign or foreign-born population in selected OECD countries

Thousands and percentages

\begin{tabular}{|c|c|c|c|c|c|}
\hline & \multicolumn{2}{|c|}{ Thousands } & \multicolumn{2}{|c|}{$\%$ of total population } & $\begin{array}{c}\text { Annual growth over } \\
\text { the period } \\
(\%)\end{array}$ \\
\hline & 1989 & 1999 & 1989 & 1999 & \\
\hline Australia & $3753^{1}$ & 4482 & 22.3 & 23.6 & 2.2 \\
\hline Austria & 387 & 748 & 5.1 & 9.2 & 6.8 \\
\hline Belgium & 881 & 897 & 8.9 & 8.8 & 0.2 \\
\hline Canada & $4343^{1}$ & $4971^{2}$ & 16.1 & 17.4 & 1.9 \\
\hline Czech Republic & $41^{5}$ & 229 & 0.4 & 0.4 & 27.8 \\
\hline Denmark & 151 & 259 & 2.9 & 4.9 & 5.6 \\
\hline Finland & 21 & 88 & 0.4 & 1.7 & 15.3 \\
\hline France & $3597^{3}$ & 3263 & 6.3 & 6.3 & -1.1 \\
\hline Germany & 4846 & 7344 & 7.7 & 8.9 & 4.2 \\
\hline Hungary & $138^{4}$ & 127 & 1.3 & 1.3 & -1.6 \\
\hline Ireland & 78 & 118 & 2.3 & 3.2 & 4.2 \\
\hline Italy & 490 & 1252 & 0.9 & 2.2 & 9.8 \\
\hline Japan & 985 & 1556 & 0.8 & 1.2 & 4.7 \\
\hline Korea & 47 & 189 & 0.1 & 0.4 & 14.9 \\
\hline Luxembourg & 107 & 159 & 27.9 & 36.0 & 4.1 \\
\hline Netherlands & 642 & 652 & 4.3 & 4.1 & 0.1 \\
\hline Norway & 140 & 179 & 3.3 & 4.0 & 2.4 \\
\hline Portugal & 101 & 191 & 1.0 & 1.9 & 6.6 \\
\hline Slovak Republic & $11^{6}$ & 29 & 0.2 & 0.2 & 17.9 \\
\hline Spain & 250 & 801 & 0.6 & 2.0 & 12.4 \\
\hline Sweden & 456 & 487 & 5.3 & 5.5 & 0.7 \\
\hline Switzerland & 1040 & 1369 & 15.6 & 19.2 & 2.8 \\
\hline United Kingdom & 1812 & 2208 & 3.2 & 3.8 & 2.0 \\
\hline United States & $19767^{3}$ & 28180 & 7.9 & 10.3 & 4.0 \\
\hline
\end{tabular}

Note: for Australia, Canada and the United States, the data are those for the foreign-born Population. For the rest, they concern those of foreign citizenship. For this and other reasons, the data are not fully comparable across countries. For more details, see Technical Note 3.
1. 1991
2. 1996
3. 1990
4. 1994
51992
6. 1993

Sources: OECD International Migration Database; OECD Labour Force Statistics. 
The categories of immigrants ${ }^{5}$ have also changed. Immigration for family reasons continues to predominate, notably in the traditional immigration countries, such as Canada, France and the United States. ${ }^{6}$ But since 1997, owing to regional conflicts and also to restrictions on other channels of immigration, the number of asylum seekers and refugees has risen substantially in many OECD countries, particularly in some European countries. In 2000, the United Kingdom, Germany and the United States received the largest number of asylum requests. When inflows of asylum seekers in the same year are expressed as a proportion of the total foreign population, Ireland, the Netherlands, Hungary and Norway rank high with over 6 per cent. In the United States, this group accounted only for two people per thousand of the foreign-born population. The profile (including country of origin) of asylum seekers and refugees may deviate from that of other immigrants which, together with the different motive behind this migration, may affect their prospects of integration, although for some of them economic motives may also have played a role.

Immigration for employment purposes have also become more important during the second half of the 1990s reflecting the period of strong economic expansion at the end of the 1990s and, in particular, the development of the information technology sector where some countries have experienced shortages of skilled and highly skilled labour. ${ }^{7}$ The rise in employment-related migration concerns also unskilled labour, as some OECD countries make extensive use of unskilled foreign labour, chiefly in agriculture, building and construction, and domestic services. That is the case in particular in Italy, Spain, Portugal, Greece and the United States. In certain countries, a substantial proportion of these foreign workers are illegal immigrants. ${ }^{8}$

Reflecting the increase in immigration during the 1980s and early 1990s, the stock of the foreign population in the OECD area rose by 14 million between 1989 and 1999, to reach nearly 58 million people (including 38 million foreign-born), equivalent to 8 per cent of the total OECD population. The countries of Southern Europe have experienced some of the largest relative rises in foreign populations, chiefly as the result of higher inflows from Central and Eastern Europe. In Belgium, France and the Netherlands, the

5. To some extent the categories used in the following (family, employment. and humanitarian or refugee migrants) are an artefact of entry policy and the data collection process. For many migrants, in whichever category, a number of different factors are behind the reason for migration.

6. In France, for example, family-linked immigration represented 75 per cent of inflows in 1999, the highest level on record and up from 60 per cent in 1995.

7. The Information Technology Association of America (ITAA) estimated a skill gap of around 425000 workers in the United States in 2001 (half the level for the year 2000), or about 4 per cent of the IT workforce (ITAA, 2001) while in the European Union, the ICT shortfall is estimated to be around 1.4 million workers in 2001 according to the European Commission (European IT Observatory Yearbook, 2001).

8. Migration statistics often underestimate the level of migration due to illegal or clandestine immigration. This category covers immigrants who enter unlawfully or overstay the expiration date of their visa or asylum seekers who remain in a country despite not having been granted political refugee status. It is obviously impossible to determine exactly how many illegal immigrants enter OECD countries. In the United States, Warren (1997) estimated that the number of illegal immigrants entering in 1996 was about 300000 , equivalent to one third of the number of legal immigrants that year. In Europe, estimates of clandestine immigration by the International Centre for Migration Policy Development have been put as high as half a million a year, implying an even larger proportion of illegal to legal immigrants. For Japan, the stock of undocumented residents was officially estimated in early 1999 at 270000 (equivalent to about one-fifth of the legal foreign population). And in Australia, the stock of temporary visitors who had failed to return on the expiry of their visa was estimated at about 53000 people in mid-1999 (DIMA, 1999), compared with an inflow of temporary residents of about 200000 in that year (and a total legal foreignborn stock of some 4.5 million). 
number of foreign nationals stagnated or fell partly because of the relatively large number of naturalisations there.

In Europe, the foreign presence in the total population is relatively high in Luxembourg (36 per cent) and Switzerland (19 per cent) but in the new immigration countries such as Finland, Italy, Portugal and Spain, as well as in Japan and Korea, the proportion of foreigners remains relatively small. Immigrants represent a particularly high proportion of the resident population in Australia (24 per cent), Canada (17 per cent) and in the United States (10 per cent); relatively high figures for these countries occur partly because their data concern the foreign-born. The proportion in Germany and Austria (9 per cent) would be somewhat lower without restrictive citizenship provisions (recently relaxed in Germany), which have meant a low level of naturalisations.

The composition of the foreign population by age, gender and levels of education differs both across countries and within countries from that of nationals. In some of the major immigration countries in Europe, such as France, the age structure for foreigners is relatively close to that for nationals reflecting long-standing migration and the fact that immigrants have tended to settle permanently in these countries; nevertheless, the proportion of working-age people is still higher among foreigners than among nationals. By contrast, more recent countries of immigration, such as those in Southern Europe and some of the Nordic countries, present a clear preponderance of groups of working age, and very marked underrepresentation of older groups. In the countries of settlement, the proportion of elderly people in the immigrant population is little different from that for nationals, reflecting probably the importance of family reunification. In some (but not all) European OECD countries, among foreigners the share of those with only a secondary level of education is much higher than among natives. This in part reflects past demands for low-skilled workers in the manufacturing sector. The gap is smaller in countries, which apply a selective policy on immigration (e.g., Canada). The dichotomy in educational attainment levels between the native and foreign population is likely to narrow, if the increasing emphasis on inflows of skilled workers continues.

\section{Effects of immigration on labour markets}

The economic effects of migration are likely to vary across countries according to the nature of migration. The main economic effects of immigration (as well as of emigration) are likely to be felt in the labour market and on public finance. Since migration affects the demographic structure of the population, including the age structure and fertility, its effects are likely to be spread through time. In this section we first examine the possible effects of immigration on labour markets and in the next section we look at fiscal impacts, but it is clear that both are related.

\subsection{Theoretical considerations}

Much of the income gain from migration accrues to the migrants: their income is likely to be significantly higher than before, whereas the gain to the host country depends on the extent to which migrants' output exceeds their incomes. But shifting labour supply between countries may have effects on the workers in the origin countries who are left behind and on the existing workforce in host countries. The effects on wages and employment and on aggregate output depend on labour market behaviour and institutions. 
Figure 2. Immigration and unemployment rates in selected OECD countries, 1998 $^{\mathrm{a}}$

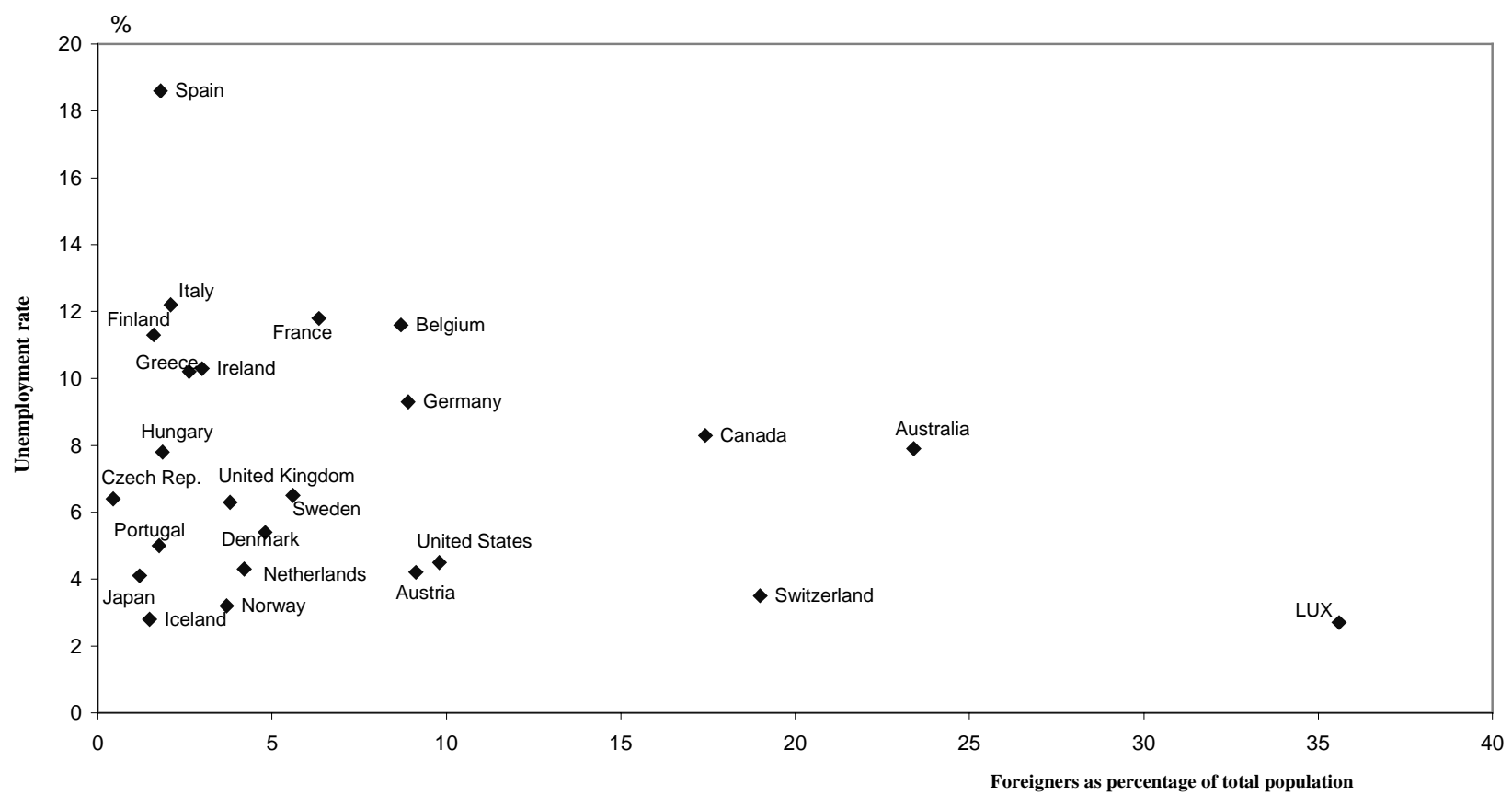

If labour markets are largely competitive, with wages for largely homogeneous labour determined by market forces (and with a fixed, or slowly adjusting, factor such as land or capital), migration reduces wages and increases employment in the host country, probably with increased unemployment for a period of adjustment (with the opposite effect in the country of origin). With less flexible labour markets, in the host country the effect on wages and employment is smaller and the unemployment effect is likely to be greater and last longer; if in the country of origin migrants have been unemployed, their departure does not (much) affect wages and employment and output. ${ }^{9}$ In the longer term, there will be adjustments to the capital stock: these can be expected to offset some of the initial changes in wages. If there are economies of scale or concentration, as is sometimes argued in the case of research- or technology-intensive activities, immigration could even increase average wages (and emigration reduce them); without increasing returns of some sort, theoretical models usually predict, however, that average wages will fall with immigration and rise with emigration.

Labour market clearing models imply that immigration will increase aggregate income in the host country by more than the income of the immigrants themselves as the existing population will gain a "migration surplus." This is because with diminishing returns immigration will cause wages to fall so that workers (with similar skills) are paid only according to the marginal product of the "last" immigrant; their average product will be higher than that and the difference accrues to capital, which will in general be owned by existing residents. See Borjas (1999) for an exposition of this. If the labour market does not clear, and immigration increases unemployment among existing residents, it is less obvious that there is automatically a gain in aggregate income of residents. However, the relatively small size of empirical estimates of the impact of immigration on unemployment among existing residents suggests that there probably is an aggregate gain even in the short run. In the longer run, more complicated mechanisms may operate as adjustments in the capital stock may reverse or partially reverse the initial movement in wages and the aggregate income gain could be larger. 


\section{Box EU enlargement and its impact on future flows of CEEC workers}

In 1993, the Copenhagen European Council agreed on the principle of enlarging the European Union to include a number of Central and Eastern European countries when conditions were appropriate. In 1998, negotiations were launched with five of these (Poland, the Czech Republic, Estonia, Hungary and Slovenia) and also with Cyprus. In February 2000, negotiations started with Bulgaria, Latvia, Lithuania, Malta, Romania and Slovakia. No firm dates have been agreed for accession, though many observers expect two waves of new entrants to occur in the second half of this decade.

Enlargement raises some apprehension in EU member countries, such as Germany and Austria, which fear large-scale inflows of workers from the CEECs, under the principle of free movement. In June 2001, the European Commission signed agreements with three candidate countries (Hungary, the Slovak Republic, Latvia) which precluded free access to the labour markets of EU countries for a maximum period of seven years after accession. The negotiation of similar treaties is underway with the other countries. Recent research to assess the impact of EU enlargement on worker migration concludes, however, that East-West flows are unlikely to have a major impact on the labour markets of the current fifteen EU countries, and that over the long term they could dwindle or possibly reverse (Boeri et al., 2002).

That report employs variables such as income differentials and employment rates in host and departure countries. The research is based on a number of assumptions, including per capita GDP convergence of 2 per cent a year between East and West, and no change in unemployment rates in the EU and the CEECs. According to these estimates, in 30 years' time, the population of CEEC origin in the current EU members would represent at most 3.5 per cent of the CEEC population. Another research paper estimates the flows at between 267000 and 336000 a year.

The immigration of workers from the CEECs would have different effects on individual EU countries, and for different categories of labour. According to Boeri et al., immigration is expected to go chiefly to Germany (65 per cent) and Austria (12 per cent). In addition, the inflows would raise competition among unskilled workers, who could be affected both by lower wages and higher unemployment.

Assuming accession by Hungary, Poland and the Czech Republic in 2005, the Austrian research institute WIFO forecasts that the number of migrants from those three countries into Austria would be 144000 in that year, and then fall off subsequently (Breuss, 2001). For Germany, two recent estimates about the immigration potential from CEEC come to different results. According to a study by the IFO institute, over a fifteen-year period after free accession, between 3.2 and 4 million immigrants from five countries (Poland, Romania, Slovak Republic, Czech Republic and Hungary) will have settled in Germany which would correspond to around 4 to 5 per cent of the population of their countries of origin. For the eight countries which the study argues to be those most likely be included in the first wave of EU membership (Estonia, Latvia, Lithuania, Poland, Slovak Republic, Czech Republic and Hungary), migration potential to Germany is estimated at 3.4 to 4.3 per cent of their population, or 2.5 to 3.3 million people. This estimate is significantly higher than one by the DIW, according to which after full mobility is implemented "only" between 1.8 and 2.4 per cent of the population of the CEECs (including Bulgaria and Romania) will migrate to Germany (Sinn et al., 2001a). 
Further complications arise from the need to consider different types of migrants, for example according to their skill levels. When migration changes both the size of the labour force and its skill composition, there are likely to be changes in both average wages and in the wage structure, with possible consequences for inequality. For example, if immigration is predominantly low skilled compared with the existing population, the wages of low-skilled workers can be expected to fall, but there may be a resulting increased demand for high-skilled workers; their wages would tend to rise; the mechanism for their real wage increase could also be increased (cheaper) supply of goods and services from the low-skilled sector. During an adjustment period, unemployment of low-skilled workers may be higher. While capital flows may respond to migration, migration may be also a response to capital flows, or may accompany such flows. Given this, and recognising that there are in fact many kinds of labour, which can be substituted for each other to a greater or lesser degree, many outcomes are possible.

\subsection{Empirical findings}

Fears have often been voiced that immigration would cause a rise in unemployment amongst native-born populations. These concerns are of particular relevance in European countries where unemployment is often high. There is no obvious relationship between the stock of immigrants and the level of unemployment (Figure 2). The results of detailed empirical studies also show that it is impossible to establish a systematic relationship between immigration and unemployment (Table 2). Nevertheless immigrants tend to have somewhat higher unemployment rates than natives (Figure 3). But is not true in all countries and can vary by sex as well as by country of origin and by type of migrant - immigrants admitted under employment-related programmes are generally employed, at least when they arrive. Given that migrants are often self-selected to be more highly motivated than average (at least in the country of origin) possible explanations for their sometimes above-average unemployment may lie in their greater concentration in vulnerable groups, or perhaps in discrimination against them; their entitlement to welfare payments such as social assistance payments and (once they meet eligibility requirements) unemployment benefit is no greater than that of equivalent natives, so this cannot easily explain a differential between immigrants and natives.

There are striking differences in the incidence of unemployment for immigrants across OECD countries. In 1999 many European countries recorded unemployment rate for foreigners two to three times that of their national counterparts. By contrast, in the settlement countries (Australia, Canada and the United States) the disparity in unemployment rates for foreigners and native-born people is much narrower. Participation rates of foreigners are also very contrasted across countries. In Denmark, the Netherlands and Sweden participation rates are much lower for foreigners than for nationals, while in Germany, France, Belgium, and Portugal, the discrepancy is significantly narrower. These differences in unemployment and participation rates between foreigners and nationals are even more pronounced for women than for men. 


\section{Figure 3. Unemployment rates of national and foreign populations (men)}

average $1999-2000^{1}$

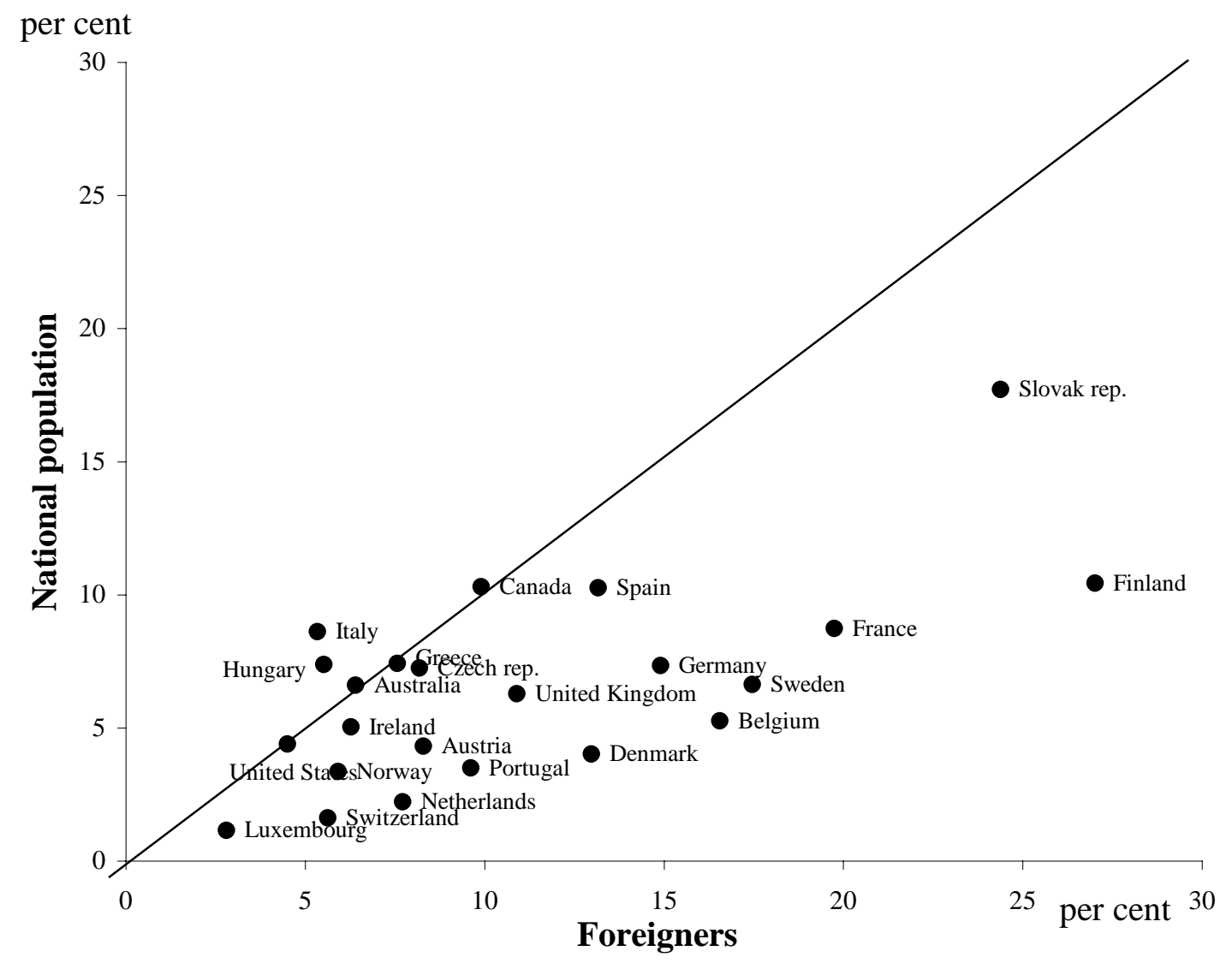

1. For Australia: august 2000; Canada: 1996; United States: march 2000;

Note : For Australia, Canada, Hungary and United States data refer to the native and foreign-born populations. Sources: Labour force surveys, results supplied by Eurostat and by Australian Bureau of Statistics:

1996 Census, Statistics Canada; Current Population Survey, Us Bureau of the Census. 
Figure 4. Barriers to entrepeneurship (1), 1998

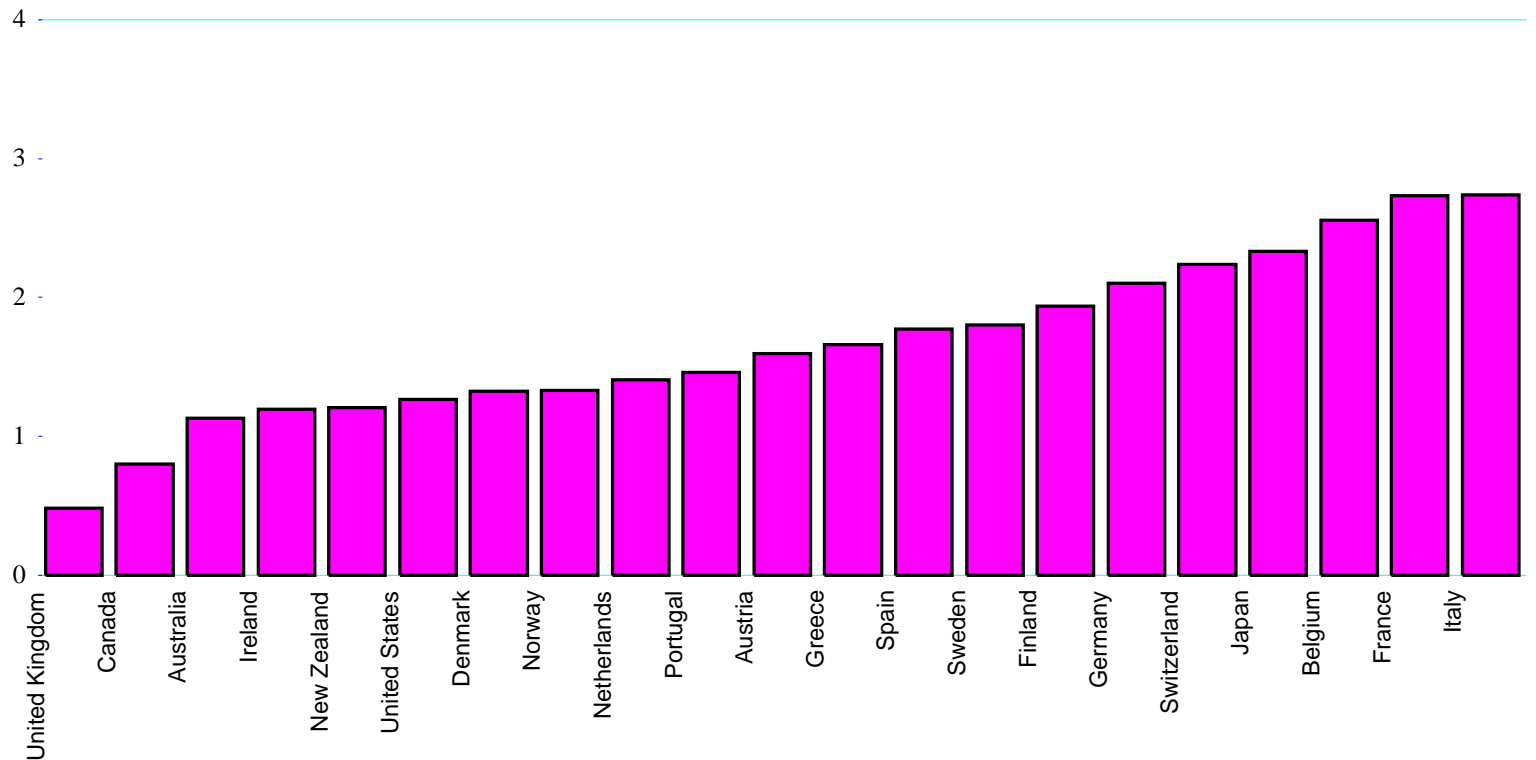

1. The scale is 0-6 from least to most restrictive.

Source: OECD, Economic Outlook, $N^{\circ} 66$.

Large labour market imbalances between foreigners and nationals may be explained by comparing the educational attainment of immigrants across countries. High unemployment and low participation rates among foreigners could be limited to those with low education attainment and hence low earnings capacity. Indeed, an important motive behind acquiring more education is to gain a stronger foothold in the labour market and thus lower the risk of unemployment. The reduction in risk is particularly large for those investing in upper-secondary education, whereas the gap in unemployment rates between upper-secondary and university-educated workers is comparatively small. Moreover, educated workers are more likely to participate in the labour market, and their active working life is generally longer than that those with lower educational attainment (OECD, 2001b). A recent OECD study using data from the European employment survey estimated the determinants of the probability of being in work by age, gender, level of education, place of birth and nationality. The results indicated that foreigners have a greater probability of being nonactive or looking for work. However, educational attainment has a large positive and significant impact on the probability to be employed in all the countries reviewed (OECD, 2001c).

Recent increases in admission of refugees or asylum seekers may also contribute to the large figures for foreign unemployment (when allowed to seek employment), especially in some OECD countries where labour market conditions are relatively unfavourable for low-skilled workers. For example, foreigners admitted as refugees or asylum seekers face considerable difficulties in some countries in finding work, due in particular to language problems in the early years of their stay. This may account for the high rate of unemployment among foreigners in Denmark, Norway and Sweden, where the annual flows of refugees or asylum seekers are relatively high compared with other admission categories.

Immigrants also tend to have lower wages than natives. As time passes, there appears to be convergence on both counts, though in some countries there is still a difference between the experience of third-generation 
immigrants (i.e., the grandchildren of immigrants) and natives, though less than there was for their grandparents, in others there appears to be no difference. It should, however, be noted, that few studies looking at this issue have been able to use time series or panel data allowing a comparison that takes into account, for example, the possibility that later waves of immigrants have different abilities from earlier ones (see Borjas (1999)). As far as educational attainment is concerned, second-generation immigrants do tend to achieve better education qualifications than their parents.

The theoretically predicted negative relation between migration and wages, or positive effect on employment and short-term unemployment have also been detected in some econometric studies, though the statistical relationship is often weak and not well-determined. But there are also a number of studies showing the opposite relationship. Tables 2 and 3 present the basic results of a selection of econometric studies.

There are many reasons why it may be difficult econometrically to establish a robust relationship between migration and the labour market. Among these are the fact that variations in migration flows are for the most part relatively small so time-series effects will be easily obscured by other developments, whereas cross-section analysis has to take account of country- or region-specific effects. Furthermore, as noted above, migration takes place for many different reasons and labour market insertion may well depend on whether immigrants expect to be in the host country temporarily or permanently. Simultaneity is also likely to be a problem, as migrants can be expected, in so far as they have any choice, to migrate to places where, or at times when, labour market prospects are most favourable. Even where specific events allow study of large, exogenous movements of people, it is still not easy to identify the expected effects . ${ }^{10}$

10. In May 1980 there was a large movement of migrants from Cuba to Florida, as 125000 people made the crossing in what became known as the Mariel boatlift. The population of Miami increased by 7 per cent. Such a sudden increase in population should provide an opportunity to detect an effect of immigrants on the labour market. One study came up with mixed conclusions (Card 1990). There was no observed effect on wages or unemployment for most of the local labour market, with the exception of already resident Cubans, whose wages fell. But it does appear that there were changes in domestic migration such that the growth rate of Miami's population subsequently fell. This might be purely coincidental, or imply highly elastic domestic migration responses to wage changes (such that the changes themselves did not show up in statistics for the directly affected region). An earlier example of a large one-off influx of migrants came in 1962 when 900000 people were repatriated from Algeria to France, increasing the labour force by around 1.6 per cent. Hunt (1992) estimated that 5 years later, in a given region, the effect of one percentage point inflow was to reduce wages in that region by 0.8 per cent and increase unemployment by 0.2 percentage points. Another example is the impact of the return of "retornados" (mostly Angolan nationals but also from Mozambique) in the mid-1970s. Over three years, some 600000 people were recorded as arriving in Portugal, largely in Lisbon, Oporto and Setubal, compared with a total population of some 9 million, though some estimates put the inflow somewhat higher. Taking this event in a longer perspective, Carrington and De Lima (1996) estimated that an immigration shock of 5 per cent of the population increased unemployment (with a lag) by 1.5 percentage points. 
Table 2. Overview of the main studies on immigration and unemployment

\begin{tabular}{|c|c|c|c|}
\hline Reference & Country studied & Data & Main findings \\
\hline $\begin{array}{l}\text { Muller and Espenshade } \\
\text { (1985) }\end{array}$ & United States & $\begin{array}{l}1970 \text { et } 1980 \text { censuses in } 247 \text { urban areas } \\
\text { and sub-sample of } 51 \text { regions in which } \\
\text { Mexican immigration is greatest } \\
\text { Proportion of persons of Mexican origin } \\
\text { in the total population }\end{array}$ & $\begin{array}{l}\text { No effect from immigration of Mexican origin on } \\
\text { the unemployment rate for the black population in } \\
\text { spite of the fact that labour supply by both } \\
\text { communities is similar }\end{array}$ \\
\hline $\begin{array}{l}\text { Withers and Pope } \\
\text { (1985) }\end{array}$ & Australia & $\begin{array}{l}\text { Quarterly longitudinal data for the period } \\
1948-1982 \\
\text { Net immigration and migration } \\
\text { (entry/exit) by permanent or long-stay } \\
\text { residents }\end{array}$ & $\begin{array}{l}\text { No significant immigration effect on unemployment } \\
\text { was identified in any of the cases. A significant and } \\
\text { slightly negative effect from immigration is however } \\
\text { found in Model } 3 \text { (elasticity close to }-0.2 \text { ) } \\
\text { The authors do find a systematic adverse effect from } \\
\text { unemployment on the net immigration flow and on } \\
\text { immigrant inflows }\end{array}$ \\
\hline $\begin{array}{l}\text { Card } \\
(1990)\end{array}$ & United States & $\begin{array}{l}\text { Examines the impact of the arrival of } \\
\text { some } 125000 \text { Cubans, largely unskilled, } \\
\text { in May } 1980 \text { in Florida. The "Mariel } \\
\text { flow" increased the population of Miami } \\
\text { by 7\%. Data are from the Current } \\
\text { Population Survey. }\end{array}$ & $\begin{array}{l}\text { Apparently Cubans alone (i.e. neither unskilled other } \\
\text { Hispanics, blacks or whites) were significantly } \\
\text { affected by this flow. But the growth of Miami's } \\
\text { population is lower, indicating a fall from other } \\
\text { sources of immigration }\end{array}$ \\
\hline $\begin{array}{l}\text { Hunt } \\
(1992)\end{array}$ & France & $\begin{array}{l}\text { Review of the impact of the repatriation } \\
\text { of } 900000 \text { settlers ("Pieds Noirs") from } \\
\text { Algeria in 1962. The total labour force } \\
\text { increased by some } 1.6 \% \text {. The author uses } \\
\text { instrumental variables to check the } \\
\text { repatriates' choice of location. }\end{array}$ & $\begin{array}{l}\text { The author estimates that a one percentage point rise } \\
\text { in the proportion of returnees in the labour force } \\
\text { reduced regional wages by } 0.8 \text { point and increased } \\
\text { the native unemployment rate by } 0.2 \text { point. }\end{array}$ \\
\hline $\begin{array}{l}\text { Pope and Withers } \\
\text { (1993) }\end{array}$ & Australia & $\begin{array}{l}\text { Annual longitudinal data for the period } \\
1861-1981 \\
\text { Net immigration rate }\end{array}$ & $\begin{array}{l}\text { Immigration was found to have a negative effect on } \\
\text { unemployment, which was especially pronounced in } \\
\text { recent times (i.e. after the second world war) } \\
\text { although observed in earlier periods as well. But the } \\
\text { lagged effect of immigration on unemployment is } \\
\text { positive, partly (but only partly) offsetting the initial } \\
\text { effect as immigrants enter the labour market and } \\
\text { adjust their consumption. }\end{array}$ \\
\hline $\begin{array}{l}\text { Marr and Siklos } \\
\text { (1994) }\end{array}$ & Canada & $\begin{array}{l}\text { Quarterly longitudinal data for the period } \\
1961-1990 \\
\text { Number of immigrants in all categories } \\
\text { combined }\end{array}$ & $\begin{array}{l}\text { Over the period 1961-78, no immigration effect on } \\
\text { unemployment is found. Over the more recent } \\
\text { period, however, the authors show that past } \\
\text { immigration significantly affects the current } \\
\text { unemployment rate. In part, these findings may } \\
\text { reflect the change in migration policy between the } \\
\text { two periods. }\end{array}$ \\
\hline $\begin{array}{l}\text { Muhleisen and Zimmermann } \\
\text { (1994) }\end{array}$ & Germany & $\begin{array}{l}\text { Individual data from the German Socio- } \\
\text { Economic Panel between } 1982 \text { and } 1989 \text {, } \\
\text { including only male private-sector wage- } \\
\text { earners aged } 17 \text { to } 52 \text { in } 1982 . \\
\text { Proportion of foreigners in local industry }\end{array}$ & $\begin{array}{l}\text { The authors rule out the hypothesis that the } \\
\text { proportion of foreigners in local employment may } \\
\text { have an impact on worker mobility or exposure to } \\
\text { unemployment. They also show that foreigners are } \\
\text { not significantly distinct from natives when all their } \\
\text { individual characteristics are taken into account. }\end{array}$ \\
\hline
\end{tabular}


Table 2. contd. Overview of the main studies on immigration and unemployment

\begin{tabular}{|c|c|c|c|}
\hline Reference & Country studied & Data & Main findings \\
\hline $\begin{array}{l}\text { Carrington and De Lima } \\
(1996)\end{array}$ & Portugal & $\begin{array}{l}\text { Studies the impact of the return of } \\
\text { Angolan nationals (retornados) to } \\
\text { Portugal in the mid-1970s. Over three } \\
\text { years, some } 600000 \text { people arrived in } \\
\text { Portugal, largely in Lisbon, Oporto } \\
\text { and Setubal, increasing the total } \\
\text { population by some } 10 \% \text {. }\end{array}$ & $\begin{array}{l}\text { Because the influx coincided with a cyclical } \\
\text { downturn in Portugal, the authors check against } \\
\text { economic trends in Spain and find that additional } \\
\text { immigration of 5\% between } 1963 \text { and } 1981 \text { had no } \\
\text { instantaneous effect, but a lagged effect equivalent } \\
\text { to an additional } 1.5 \text { percentage points of } \\
\text { unemployment. }\end{array}$ \\
\hline $\begin{array}{l}\text { Gross } \\
(2000)\end{array}$ & France & $\begin{array}{l}\text { Quarterly longitudinal data between } \\
1974 \text { and } 1995 \text {, adjusted for the } 1981 \\
\text { regularisation programme } \\
\text { Rates of worker immigration and } \\
\text { family immigration }\end{array}$ & $\begin{array}{l}\text { Immigration has a strong adverse effect on } \\
\text { unemployment over the long term (even allowing } \\
\text { for family immigration) and a positive, albeit very } \\
\text { slight, effect in the short term }\end{array}$ \\
\hline
\end{tabular}


Table 3. Overview of the main studies on immigration and wages

\begin{tabular}{|c|c|c|}
\hline Source & Data & Main findings \\
\hline $\begin{array}{l}\text { Grossman } \\
(1982)\end{array}$ & US Census 1970 & $\begin{array}{l}\text { Effect from a } 10 \% \text { rise in the total number of foreigners on the wages } \\
\text { of: } 2^{\text {nd }} \text { generation }-2 \% \text {; nationals }-3 \%\end{array}$ \\
\hline $\begin{array}{l}\text { Borjas } \\
(1983)\end{array}$ & $\begin{array}{l}\text { Survey of Income and } \\
\text { Education } 1976\end{array}$ & $\begin{array}{l}\text { Blacks and Hispanics are complementary. Hispanics and whites are } \\
\text { also complementary. Slight econometric evidence of black/white } \\
\text { substitutability. }\end{array}$ \\
\hline $\begin{array}{l}\text { Chiswick \& Miller } \\
(1985)\end{array}$ & 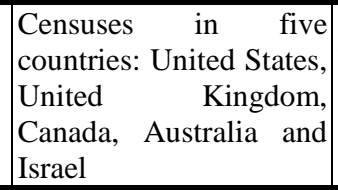 & $\begin{array}{l}\text { Strong substitution nationals-migrants. The greater the supply, the } \\
\text { lower the relative income of immigrants }\end{array}$ \\
\hline $\begin{array}{l}\text { Geary \& Grada } \\
(1985)\end{array}$ & $\begin{array}{l}\text { Time series of } \\
\text { immigration data and } \\
\text { economic variables }\end{array}$ & $\begin{array}{l}\text { Adverse but modest effect from immigration on wages; Granger } \\
\text { causality of a change in immigration on wages }\end{array}$ \\
\hline $\begin{array}{l}\text { Muller \& Espenshade } \\
(1985)\end{array}$ & US census, 19701980 & $\begin{array}{l}\text { Complementarity immigrants-natives. Mexican immigration has little } \\
\text { impact on the income or unemployment of black households. }\end{array}$ \\
\hline $\begin{array}{l}\text { Borjas } \\
(1986)\end{array}$ & 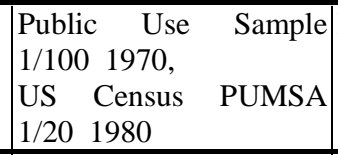 & $\begin{array}{l}\text { No effect from male immigration on white men's wages. } \\
\text { Complementarity with black men. }\end{array}$ \\
\hline $\begin{array}{l}\text { Borjas } \\
(1987)\end{array}$ & $\begin{array}{|lrr|}\text { US Census } & 5 / 1 & 000 \\
1980\end{array}$ & $\begin{array}{l}\text { A } 10 \% \text { increase in WI lowers WN wages by } 0.3 \% \text {. A rise in } \mathrm{HI} \\
\text { raises BN wages by } 0.1 \% \text { and HN wages by } 0.2 \% \text {. No effect on WN }\end{array}$ \\
\hline $\begin{array}{l}\text { Garson, Moulier-Boutang, } \\
\text { Silberman \& Magnac } \\
(1987)\end{array}$ & $\begin{array}{ll}1985 & \text { French } \\
\text { employment survey }\end{array}$ & $\begin{array}{l}\text { G2, G3, G4 complementary to G1. Very slight effects on wages from } \\
\text { a } 10 \% \text { increase in any of these groups. }\end{array}$ \\
\hline $\begin{array}{l}\text { Bean, Lowell \& Taylor } \\
\text { (1988) }\end{array}$ & $\begin{array}{l}\text { US Census } 1980 \text { five } \\
\text { states in the south- } \\
\text { western United States }\end{array}$ & $\begin{array}{l}\text { Effect on wages of a } 10 \% \text { increase in illegal Mexican immigrants: } \\
\text { White natives } 0 \% \\
\text { Black natives }+0.1 \% \\
\text { Hispanic natives }+0.2 \% \\
\text { The effect of legal Mexican immigration on white wages is negative } \\
\text { and slight. }\end{array}$ \\
\hline $\begin{array}{l}\text { Altonji \& Card } \\
(1991)\end{array}$ & US census (1980) & $\begin{array}{l}\text { Adverse effect of immigrants in the local population on the wages of } \\
\text { unskilled native workers, significant especially among black men. A } \\
10 \% \text { increase in immigration reduces wages by } 0.86 \% \text {. }\end{array}$ \\
\hline $\begin{array}{l}\text { Butcher \& Card } \\
(1991)\end{array}$ & 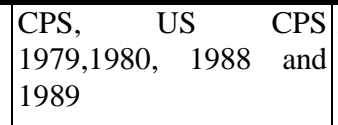 & $\begin{array}{l}\text { An increase in immigration has a non-significant effect on the lowest } \\
\text { wages and a positive effect on the highest wages. }\end{array}$ \\
\hline $\begin{array}{l}\text { Lalonde \& Topel } \\
(1992)\end{array}$ & US Census $(1970,1980)$ & $\begin{array}{l}\text { A } 50 \% \text { increase in immigration leads to a } 3 \% \text { drop in the wages of } \\
\text { "new" already settled immigrants. The impact is greater for young } \\
\text { black men. }\end{array}$ \\
\hline $\begin{array}{l}\text { De New \& Zimmermann } \\
\text { (1993) }\end{array}$ & $\begin{array}{l}\text { German GSOEP, 1984- } \\
1989\end{array}$ & $\begin{array}{l}\text { A one percentage point rise in the proportion of foreign employment } \\
\text { reduces the hourly wage by about } 4 \% \text {. The effect is not significant for } \\
\text { white collars unless they have little job experience. }\end{array}$ \\
\hline $\begin{array}{l}\text { Pischke \& Velling } \\
\text { (1994) }\end{array}$ & $\begin{array}{l}\text { Bundesforschungsanstalt } \\
\text { für Landeskunde } \\
\text { Und Raumordnung } \\
\text { (1992), Data for } 1985 \\
\text { and 1989 }\end{array}$ & $\begin{array}{l}\text { Positive but generally not significant effect of the percentage of } \\
\text { foreigners (or Turkish nationals) in the local population on the log of } \\
\text { the manufacturing wage }\end{array}$ \\
\hline
\end{tabular}


Table 3 contd. Overview of the main studies on immigration and wages

\begin{tabular}{|c|c|c|}
\hline Source & Data & Main findings \\
\hline $\begin{array}{l}\text { Gang \& Rivera-Batiz } \\
\text { (1994) }\end{array}$ & $\begin{array}{l}\text { US Census, } \\
\text { Eurobarometer } \\
\text { Netherlands } \\
\text { France } \\
\text { United Kingdom } \\
\text { Germany }\end{array}$ & $\begin{array}{l}\text { Unskilled labour, education and experience are found to be } \\
\text { complementary for the entire population in the United States and in } \\
\text { Europe. This explains why the effects of immigration are so complex. } \\
\text { In Europe, the various ethnic groups supply labour having very low } \\
\text { substitutability for that of nationals (except for Asians in France: } \\
\text { elasticity -0.1). In the United States, complementarity effects between } \\
\text { immigrants and nationals from the various communities dominate as } \\
\text { well. }\end{array}$ \\
\hline $\begin{array}{l}\text { Borjas, Freeman \& Katz } \\
\text { (1996) }\end{array}$ & $\begin{array}{l}\text { US Census } 1980 \text { and } \\
1990\end{array}$ & $\begin{array}{l}\text { The regression shows wages to be positively correlated with the } \\
\text { percentage of immigrants, except for men in } 1980 \text {. However, the } \\
\text { findings are not very robust. } \\
\text { With the other method, the authors show that immigration is } \\
\text { responsible for roughly } 30 \% \text { of the earnings decline for high school } \\
\text { dropouts between the two dates. }\end{array}$ \\
\hline $\begin{array}{l}\text { Dolado, Jimeno \& Duce } \\
\text { (1996) }\end{array}$ & $\begin{array}{l}\text { Permit data } \\
1990-92 \\
\text { Spain }\end{array}$ & $\begin{array}{l}\text { A } 1 \% \text { increase in immigration raises wages by } 1 / 20^{\text {th }} \text { of } 1 \% \text { for } \\
\text { skilled workers and by } 1 / 20^{\text {th }} \text { of } 1 \% \text { for unskilled workers. The } \\
\text { authors justify these results by Spain's low level of immigration and } \\
\text { the existence of a threshold effect. }\end{array}$ \\
\hline $\begin{array}{l}\text { Margo } \\
(1997)\end{array}$ & $\begin{array}{l}\text { Historical data on the } \\
\text { California Gold Rush }\end{array}$ & $\begin{array}{l}\text { Wages dropped significantly at the beginning of the influx of } \\
\text { immigrants (1848-1852) and then remained constant. }\end{array}$ \\
\hline $\begin{array}{l}\text { Camarota } \\
(1998)\end{array}$ & $\begin{array}{ll}\text { Current } & \text { Population } \\
\text { Survey (June } & 1991)\end{array}$ & $\begin{array}{l}\text { Immigration exerts downward pressure on wages: A one percentage } \\
\text { point (about } 10 \% \text { ) rise in the proportion of immigrants translates into } \\
\text { a } 0.5 \% \text { drop in the average wage and a } 0.8 \% \text { decline in unskilled } \\
\text { wages. }\end{array}$ \\
\hline $\begin{array}{l}\text { Butcher \& DiNardo } \\
\text { (1998) }\end{array}$ & $\begin{array}{l}\text { US Census 1960, 1970, } \\
1980,1990\end{array}$ & $\begin{array}{l}\text { The authors show that if the wage structure had not shifted between } \\
1970 \text { and } 1990 \text {, there would have been little change in the earnings } \\
\text { differential between natives and immigrants. The influx of } \\
\text { immigrants over the period is therefore not responsible for changes in } \\
\text { the relative distribution of wages. }\end{array}$ \\
\hline $\begin{array}{l}\text { Pedace } \\
(1999)\end{array}$ & US Census 1980, 1990 & $\begin{array}{l}\text { An increase in the proportion of immigrants in the primary sector } \\
\text { generally feeds through to higher wages. In the secondary sector, } \\
\text { wages are positively correlated with the proportion of foreigners, } \\
\text { with the exception of Hispanics (men and women) and black women. } \\
\text { In all cases, the effects are slight and not robust. }\end{array}$ \\
\hline $\begin{array}{l}\text { Jayet \& Rajaonarison } \\
(2001)\end{array}$ & $\begin{array}{lc}\text { France: } & 1990-1997 \\
\text { employment } & \text { surveys } \\
\text { SEDDL } & \text { regional } \\
\text { database } & \end{array}$ & $\begin{array}{l}\text { Significant, positive but slight effect of the presence of foreigners on } \\
\text { the wages of men and women. } \\
\text { The findings are less robust when looking specifically at North } \\
\text { Africans or citizens of southern European countries. } \\
\text { At the level of socio-professional categories, the (still positive) } \\
\text { relationship seems to be validated only for skilled male workers. }\end{array}$ \\
\hline $\begin{array}{l}\text { Borgas } \\
(2002)\end{array}$ & $\begin{array}{l}\text { US microdata samples } \\
\text { of the Dicennial Census } \\
(1960,1970, \quad 1980, \\
1990) \text { and Annual } \\
\text { Supplement of the } \\
\text { Current Population } \\
\text { Survey (1999, 2000, } \\
2001)\end{array}$ & $\begin{array}{l}\text { An immigrant influx that increases the supply of workers with } \\
\text { particular skills by } 10 \% \text { lowers the wage of natives in that group by } \\
2-3 \% \text {, and reduces their weeks' worked by } 2 \% \text {. }\end{array}$ \\
\hline
\end{tabular}


A different but related issue is how international migration may be related to internal mobility. One interesting argument (due to Borjas (2001)) is that immigration may contribute to improving domestic factor utilisation by compensating for the reluctance of natives to move from areas of (relative) labour surplus to areas of shortage. Regional (or, in principle, skill-specific) labour market imbalances can be A different but related issue is how international migration may be related to internal mobility. One interesting argument (due to Borjas (2001)) is that immigration may contribute to improving domestic factor utilisation by compensating for the reluctance of natives to move from areas of (relative) labour surplus to areas of shortage. Regional (or, in principle, skill-specific) labour market imbalances can be quite persistent, as people are reluctant to move long distances to look for work or higher wages. This may be for family reasons, but also may be related to welfare policy or housing market flexibility, for example. Borjas argues that immigrants into the United States, who face no such costs prior to immigration, are less constrained in their choice of region of settlement and tend to choose those where labour markets are tighter. This possibility has to be set against another observed tendency of migrants, which is to settle in areas where migrants from the same country have gone before, because of network effects. It is not necessarily the case that such areas will be those where labour markets are currently the tightest, even if other things being equal - labour market conditions are important for the decision to migrate.

\subsection{Integration of immigrants in the longer term}

As was emphasised earlier, the effects of migration cannot easily be understood by looking at short-run effects. Migration has effects on demography which themselves depend on the age and sex structure of the migrant population and its fertility behaviour (which tends to converge on that of host populations, but only slowly). This will have significant effects on the economy in general and the labour market in particular, but identifying them in a useful way is not attempted here. One set of issues that can be identified and where there is an extensive literature is the longer run integration of individual (groups of) migrants into the labour market. One of the most important questions for the migrants themselves is to what extent they or their descendants "catch up" on natives. There are a number of senses in which this can be measured. One is that for given skills they have the same employment and wage prospects, another (given that skills are often proxied by educational attainment) is that their children reach the same educational level as natives, so that they in turn become indistinguishable, on this measure, from natives. Differences in the labour market between natives and migrants are not due only to their different economic characteristics, of course. Direct or indirect discrimination against foreigners is common, tending to vary by ethnic group.

\section{Fiscal effects of immigration}

Public concern that immigration could be a heavy burden for the native population has a long tradition. Even before welfare states were established, there were fears in immigrating countries that the influx of foreign paupers could reduce the living standard of the natives via an extensive use of urban infrastructure, together with a deterioration in the outer appearance of cities. Policies to limit the inflow of people who were deemed likely to become recipients of public assistance programmes have a long tradition. ${ }^{11}$ The establishment of social aid programmes and the extension of the welfare state during the twentieth century

11. For example in 1891, the US Congress acted to restrict entry of various "classes" of people, particularly paupers. Those who were perceived as a potential public burden were turned away at ports of entry and transport companies were required to return them. Furthermore, in order to deter paupers and to help to finance social services a head tax on each arrival was introduced and steadily increased between 1882 and 1907. Those who became public charges (paupers) within a year of entry were subject to deportation (Jensen 1989). 
has raised the potential drain of public resources by poor immigrants and there is often the perception that immigrants add significantly to government outlays on social spending and reduce the claims of natives on the public capital stock.

Apart from their effect on public spending, most immigrants pay direct or indirect taxes, and business taxes would increase too (assuming taxable profits or value added increase). ${ }^{12}$ Such tax and expenditure effects may occur at all levels of government - federal, regional, local, social security. Furthermore, the immigration-induced increase in GDP may also increase total government revenues by more than those paid directly by immigrants. Thus, a broader approach is needed to assess the overall fiscal effect of immigration. The effects have to consider not only spending in individual programmes but general spending and overall tax payments. Furthermore, a static approach, which looks only at the budgetary effects in a specific period, may be not enough as it disregards the dynamic budget effects, i.e. the effects over the entire lifetime of immigrants, including that of their children.

The fiscal impact of immigration depends on the characteristics of immigrants (e.g. family status, employment, level of income) and also varies from country to country, depending on, for example, the tax and welfare systems, labour market flexibility and institutions, as well as general economic conditions. Some argue that there is an interaction, via the material interest of average voters, between immigration and welfare programs although this is difficult to predict. In the following we discuss briefly the literature on possible effects of immigration on welfare systems from a public choice point of view, We then examine the various approaches to measure the effects of immigration on government budgets and review the empirical literature on such effects in the various OECD countries.

\subsection{Effect of immigration on welfare systems - the political economy aspect}

There is a lively literature on political economics (public-choice school) that emphasises the political process in understanding fiscal policy decisions (see Persson and Tabellini, 1999, for a literature survey). Some theoretical models are based on the median voter theorem. In these models, for example, the size of redistributive fiscal programmes would reflect the preference of the median voter (in practice, this may correspond to the middle-income class). In a society with a relatively well-off middle class and the poverty concentrated at the low end of the income scale, the amount of redistribution may be small, while with a relatively worse-off middle class and unequal income distribution, the majority of the voters may prefer a large redistributive spending (and high income tax rates). In such a framework, immigration could upset the political balance among different socio-economic groups and lead to a change in policies. For example, if immigrants are relatively poor so that they are likely to be net beneficiaries of the fiscal transfers, this can actually lead to a reduction in redistributive spending programmes and tax rates. It is because the additional tax burden on the middle class from the need to finance the transfers to the immigrants can cause the middle class to shift toward anti-tax coalition. While immigrants and poor natives would prefer higher redistributive spending (and higher taxes) ${ }^{13}$, the median voter (and tax payer) who dominates the political process may prefer lower tax rates.

It is argued that higher wages and more generous welfare systems in Western European countries attract immigrants from Eastern Europe (in particular after EU enlargement) and from other countries and this

\footnotetext{
12. The effects could be complex. Employment of migrants may increase profits and, thus, revenues from business taxes. But if the increased labour supply reduces wages (and/or) the employment of native workers, this would reduce (net) revenues from native employment, while on the other hand further increasing profit taxes.

13. If the poor expect (for themselves or their children) to achieve in the future a higher level on the income ladder, they may, however, not support a high level of income redistribution and high taxes.
} 
will lead Western European countries to scrutinise their welfare systems and try to avoid being welfare magnets. A successive dismantling of the European social welfare state could be the likely outcome (Sinn, 2002). Unskilled or poor natives would then be affected by immigration not only by reducing their wages and employment opportunities but in addition via a reduction in redistributive programmes. Razin et al. (1998) and Razin and Sadka (2000) provide some empirical evidence for such effects of immigration. Alesina et al. (1998) find that ethnic fragmentation in US cities is negatively related to the supply of public goods and services (education, roads, libraries, sewers and trash collection) and local spending on welfare. Woo (2002) reports that income inequality is an important determinant of public sector deficits in a panel of industrial and developing countries. This suggests that large income inequality can be associated with resistance both to cut existing spending programmes (from the poor) and to increasing taxes (from the rich) so that deficits can surge.

There are also some studies that point in the opposite direction. For example, Rodrik (1998) makes a strong case that the size of redistributive spending is positively related to the exposure of societies to risks from globalisation. Public welfare is seen as to provide social insurance to people who are vulnerable to external shocks. Indeed, more open economies were found to spend more on welfare (and have bigger governments). While in this literature "openness" of an economy is generally proxied by the trade share of GDP, it can also include openness to immigration across borders (or labour mobility in a broad sense). Hence, greater labour mobility (including immigration) would be accompanied by greater social welfare spending (and possibly higher taxes) because of increased demand for social protection from the native workers who face greater risks associated with globalisation process. The upshot of this recent public choice literature is that immigration can lead to changes in existing welfare systems, although the size and even the sign of any resulting changes may be difficult to predict. If there is more pressure on welfare spending, this can lead to more cost-effective programmes instead. The political-economy analysis in the context of migration is further complicated by the fact that immigrants are not typically entitled to vote until they obtain citizenship, which some never do.

\subsection{Measurement approaches of fiscal effects of immigration}

The measurement approaches applied in the literature differ with respect to the coverage of government spending and revenues, as well as the time horizon (for a survey, see Blanchet (1997)). Some studies examine the direct budgetary effects caused by settlement services and general spending programmes, and on taxes paid by immigrants; here, the federal government level or the general government, including social security budget, is considered. Other studies include the budgetary effect of the immigration-induced change on the overall economy (i.e. the change in net taxes paid by the existing population). Both static and dynamic (which may or may not use longitudinal data) approaches are applied. Static approaches could be misleading as they do not consider the different fiscal impacts of migration over time. For example, school-age migrants receive educational services or other age-related transfers and may appear to be a burden on the government budget. But, when they enter the workforce and pay taxes, these may be higher (in present value terms) than the overall benefits which they receive from the State. Or, if workingage immigrants enter the country and immediately pay taxes and social security contributions, the fiscal pressure is reduced. However, later in life they will get pensions, so that their overall contribution to the budget may be smaller than it first appears.

The concept of generational accounting has been applied in order to assess the fiscal effects of immigration in a dynamic framework. It looks at budgetary effects of immigration after the arrival of immigrants, and over their remaining lifetime (in present value terms). Applying this approach requires (among other things) information (or assumptions) on benefits received, and taxes paid, by immigrants over their remaining lifetime. Measuring the long-term net tax payments of immigrants to the government (in present value terms) is particularly important when examining the effect on pension systems, as it includes not 
only current contributions by immigrants but also - and in particular - their future pension benefits. Given the fact that in many countries the ageing of the population requires additional measures to achieve longterm fiscal sustainability in pension (and health care) systems, the question examined in these studies is whether, and to what extent, immigration helps to reduce future fiscal pressures of ageing population (see below). A dynamic approach is also useful to analyse the long-term fiscal effects of migrants entering the country at different ages, and of children born to migrants in the host country.

It is clear that estimated fiscal impacts of immigration depend heavily on the approach used, and on the assumptions underlying the various estimates. Estimates of the fiscal effect could refer to the existing stock of immigrants, or to recent inflows which could be quite different in composition.

\subsection{The ageing perspective}

If new immigrants are of working age, with lower proportions of both children and older people immigration could act as a temporary brake on the future upward trend in old-age dependency ratios in OECD countries. ${ }^{14}$ Migration also has a long-term impact, especially if immigrants have higher fertility rates than the existing population. Hence, part of the fiscal benefits from immigration identified in the studies discussed above arises from the changed age structure. ${ }^{15}$ Given the fact that in many countries the ageing of the population requires additional measures to achieve long-term fiscal sustainability in pension and health care systems, the question arises if and to what extent immigration could help to reduce future fiscal pressures.

The effects depend on assumptions about pensions and health care expenditures and future reforms, as well as life expectancy. For example, an immigrant joining an actuarially-fair, defined-contribution, public pension scheme will not create any benefit to the pension system. The effect of joining - or, in the case of emigrants, leaving - a PAYG scheme will vary according to whether the scheme has been reformed to make it sustainable. Where it is not, immigration could help under certain conditions to eliminate the fiscal imbalance, as is illustrated by several of the generational accounting studies as discussed below. The view that higher immigration alleviates part of the fiscal burden of age-related spending is supported by a sensitivity analysis, which has been carried out in the context of projections of long-term fiscal costs of ageing in OECD countries (Dang et al., 2001). The effect is noticeable, but the simulations indicate that very substantial immigration would be necessary to make a significant offset to the public finance implications of ageing in most countries (Table 4).

The results of some of the existing studies on fiscal effects of immigration are summarised in Table 5 and a more detailed description is presented in the Annex.

14. Since immigrants inevitably grow old too, the long-run effect on overall demographics is much less than in the short term and medium term; in order to make a big difference to trends in the dependency ratio without increases in fertility, large and ever-increasing volumes of migration might be needed. See United Nations (2000).

15. For example, Sinn (2001) calculates that the gain (in present value terms) to the German social security system caused by an immigrant is nearly twice as much as the value of a German newborn child. The reason is that immigrants immediately pay social security contributions and also have more children, so that the benefits to the social security system also extend to later generations. 


\section{Policy issues}

As the previous discussion has suggested, the effects of migration depend very much on the characteristics of the migrants. Hence, migration-related policies need to take account of this diversity, as well as of the fact that migration and its effects are not just economic phenomena. Furthermore, some policies that might

have advantages from an abstract economic point of view are likely to be unrealistic or unacceptable in practice, depending on the different views and traditions in different countries. ${ }^{16}$ But there are nevertheless many areas where appropriate policy choices can increase the benefits to be expected from migration or reduce adverse effects from it.

One group of issues is concerned with policies which affect the volume or composition of migration flows. Partly this is to do with migration controls themselves - this means in practice controls on immigration rather than on emigration. To start with, it is necessary to have a clear idea of what the aims of immigration

\section{Table 4. Sensitivity of pension spending to higher immigration}

\begin{tabular}{|c|c|c|c|c|c|c|c|c|}
\hline & \multicolumn{4}{|c|}{ Net immigration (number of persons) } & \multicolumn{2}{|c|}{$\begin{array}{l}\text { Additional stock of } \\
\text { foreigners in } 2050 \\
\text { (Against baseline } \\
\text { scenario) }\end{array}$} & \multicolumn{2}{|c|}{$\begin{array}{l}\text { Changes in old-age pension } \\
\text { spending } \\
2000-2050 \\
\text { (in percentage points of GDP) }\end{array}$} \\
\hline & Baseline & enario & $\begin{array}{r}\text { High imm } \\
\text { scen }\end{array}$ & $\begin{array}{l}\text { igration } \\
\text { ario }\end{array}$ & $\begin{array}{l}\text { High imm } \\
\text { scena }\end{array}$ & $\begin{array}{l}\text { nigration } \\
\text { lario }\end{array}$ & $\begin{array}{l}\text { Baseline } \\
\text { scenario }\end{array}$ & $\begin{array}{c}\text { Higher } \\
\text { migration } \\
\text { scenario } \\
\text { difference from }\end{array}$ \\
\hline & 2000 & 2050 & 2000 & 2050 & $\begin{array}{c}\text { Number of } \\
\text { persons }\end{array}$ & $\begin{array}{c}\% \text { of } \\
\text { population }\end{array}$ & & \\
\hline Belgium & 10,204 & 15,000 & 11,224 & 22,500 & 495,916 & 4.9 & 3.3 & -0.4 \\
\hline Czech Republic & 9,500 & 15,000 & 10,100 & 22,500 & 347,946 & 4.2 & 6.8 & -0.3 \\
\hline Denmark & 11,000 & 10,000 & 12,100 & 15,000 & 335,517 & 6.1 & 2.7 & -0.2 \\
\hline France & 50,094 & 50,000 & 55,103 & 75,000 & $1,677,682$ & 2.7 & 3.9 & -0.3 \\
\hline Germany & 300,000 & 200,000 & 330,000 & 300,000 & $6,668,965$ & 8.8 & 5.0 & -1.0 \\
\hline Italy & 50,000 & 80,000 & 55,000 & 120,000 & $2,424,622$ & 5.0 & -0.3 & -0.5 \\
\hline Spain & 31,054 & 60,000 & 34,159 & 90,000 & $1,790,314$ & 5.1 & 8.0 & -0.8 \\
\hline Sweden & 15,165 & 20,000 & 16,682 & 30,000 & 671,486 & 7.3 & 1.6 & -0.7 \\
\hline United States & 900,000 & 900,000 & 900,000 & $1,350,000$ & $28,105,264$ & 7.8 & 1.8 & -0.3 \\
\hline
\end{tabular}

16. For example, a discriminatory approach to non-contributory welfare payments - e.g., making provision for immigrants less generous than for natives, but more generous than in countries of origin - might appear to have economic logic (and potential migrants might even find it acceptable if it lowered entry barriers) but might be socially and politically unacceptable. But see Sinn (2002) for a discussion of welfare systems based on a country-of-origin principle. 
Table 5. Some estimates of the fiscal impact of migration

\begin{tabular}{|c|c|c|c|}
\hline Country, author & Main results & $\begin{array}{c}\text { Time } \\
\text { horizon/measurement } \\
\text { approach } \\
\end{array}$ & $\begin{array}{l}\text { data: direct survey of } \\
\text { migrants }\end{array}$ \\
\hline $\begin{array}{l}\text { Australia, Access } \\
\text { Economics }\end{array}$ & $\begin{array}{l}\text { Average migrant benefits the budget } \\
\text { (by c.A } \$ 5000 \text { per year after } 10 \text { years); } \\
\text { humanitarian admissions do not. }\end{array}$ & $\begin{array}{l}\text { 6-years (extrapolated to } \\
10 \text { ) }\end{array}$ & $\begin{array}{l}\text { Longitudinal survey since } \\
\text { [1994] }\end{array}$ \\
\hline $\begin{array}{l}\text { Australia, Bureau } \\
\text { of Immigration } \\
\text { (BIR) }\end{array}$ & $\begin{array}{l}\text { Short- and medium-term (1-4 years) } \\
\text { net fiscal costs, but long-term (after } 10 \\
\text { years) net fiscal gain. }\end{array}$ & $\begin{array}{l}1-10 \text { years/ } \\
\text { macroeconomic model }\end{array}$ & 1989-90 intake of immigrants \\
\hline $\begin{array}{l}\text { Australia, Ablett } \\
\text { (1999) }\end{array}$ & $\begin{array}{l}\text { Immigrants are likely to make a } \\
\text { substantial net positive contribution to } \\
\text { the public sector. }\end{array}$ & $\begin{array}{l}\text { Generational accounting } \\
\text { model. }\end{array}$ & \\
\hline $\begin{array}{l}\text { Denmark, } \\
\text { Economic Council }\end{array}$ & $\begin{array}{l}\text { Current net emigration does "not seem } \\
\text { to threaten the Danish income tax } \\
\text { base" }\end{array}$ & & \\
\hline $\begin{array}{l}\text { Denmark, } \\
\text { Statistics Office }\end{array}$ & $\begin{array}{l}\text { Additional } 5000 \text { average immigrants } \\
\text { imply tax increase of } 0.25 \% \text { GDP; } 17- \\
\text { year-olds would be tax neutral. }\end{array}$ & CGE model & $\begin{array}{l}\text { Representative immigrant } \\
\text { group with average immigrant } \\
\text { participation, etc. }\end{array}$ \\
\hline $\begin{array}{l}\text { Germany, Bonin et } \\
\text { al. }\end{array}$ & $\begin{array}{l}200000 \text { average immigrants (net } \\
\text { annual inflow) reduce tax burden by } \\
1.1 \% \text { GDP. }\end{array}$ & $\begin{array}{l}\text { Generational accounting } \\
\text { model }\end{array}$ & $\begin{array}{l}\text { Information from labour force } \\
\text { survey and German socio- } \\
\text { economic panel }\end{array}$ \\
\hline $\begin{array}{l}\text { Germany, Sinn et } \\
\text { al. (2001) }\end{array}$ & $\begin{array}{l}\text { Immigrants are, on average, a net } \\
\text { burden to the government budget } \\
\text { (€ } 726 \text { per year and per capita during } \\
\text { their total stay and } € 2368 \text { per year } \\
\text { and per capita during their first ten } \\
\text { years). }\end{array}$ & $\begin{array}{l}\text { Base year 1997, present } \\
\text { value for pension } \\
\text { benefits. }\end{array}$ & $\begin{array}{l}\text { Information from German } \\
\text { socio-economic panel, } \\
\text { national accounts, fiscal } \\
\text { statistics, and ifo pension } \\
\text { model. }\end{array}$ \\
\hline Italy, Moscarola & $\begin{array}{l}50000 \text { immigrants per year reduce tax } \\
\text { burden by } 3-4 \% \text { GDP. }\end{array}$ & $\begin{array}{l}\text { Generational accounting } \\
\text { model }\end{array}$ & \\
\hline $\begin{array}{l}\text { United States, Lee } \\
\& \text { Miller (2000) }\end{array}$ & $\begin{array}{l}100000 \text { extra immigrants per year } \\
\text { cost } 0.7 \% \text { of fed. Revenue after } 75 \\
\text { years; total (fed/state/local) impact -ve } \\
\text { for }>25,<50 \text { years. }\end{array}$ & $\begin{array}{l}\text { Follows up to } 2^{\text {nd }} \\
\text { generation immigrants }\end{array}$ & $\begin{array}{l}\text { Congressional Budget Office } \\
\text { (Lee \& Miller (1997)); } \\
\text { Current Population Survey, } \\
\text { Census }\end{array}$ \\
\hline $\begin{array}{l}\text { United States, Blau } \\
\text { (1984) }\end{array}$ & $\begin{array}{l}\text { Immigrants receive on average higher } \\
\text { transfers than natives. This is almost } \\
\text { entirely due to the higher average age } \\
\text { of immigrants - a reflection of the } \\
\text { large inflows during the pre-1924 } \\
\text { period. }\end{array}$ & $\begin{array}{l}\text { Survey of income and } \\
\text { education, } 1976 .\end{array}$ & \\
\hline $\begin{array}{l}\text { United States, } \\
\text { Jensen (1987) }\end{array}$ & $\begin{array}{l}\text { Higher average use of public } \\
\text { assistance by immigrants, compared to } \\
\text { natives but difference is small and } \\
\text { relfects preference of immigrants to } \\
\text { live in states where economic } \\
\text { conditions and welfare benefits are } \\
\text { above average. }\end{array}$ & Bureau of Census Data. & \\
\hline $\begin{array}{l}\text { United States, } \\
\text { Storesletten (2000) }\end{array}$ & $\begin{array}{l}\text { Additional immigration has a positive } \\
\text { effect on the government budget only } \\
\text { if immigrants are selected by age and } \\
\text { skill. }\end{array}$ & CGE model. & \\
\hline $\begin{array}{l}\text { United States, } \\
\text { Auerbach and } \\
\text { Oreopoulus (1999) }\end{array}$ & $\begin{array}{l}\text { Additional immigration can alleviate } \\
\text { the implicit government debt. Results } \\
\text { depend on how measures to eliminate } \\
\text { it are distributed over time. }\end{array}$ & $\begin{array}{l}\text { Generational accounting } \\
\text { model }\end{array}$ & \\
\hline
\end{tabular}

Fiscal policy effects on the impact of migration are an important practical consideration for policymakers, and public views - not necessarily accurate - about it can have a significant impact on overall migration 
policy. Tax and benefit policy interacts with labour market policy through its effects on incentives to work and migrate.

The following sub-Sections consider a variety of policies under these headings, aiming to suggest ways in which policies can affect the degree to which economies can benefit from migration flows. The grouping used here is often rather artificial: many policies have an effect on all of labour market outcomes, budgetary outcomes and incentives to migrate; some policies have a rather direct effect and others only indirect.

\subsection{Policies affecting migration flows}

Border controls directly influence migration flows, although they cannot generally achieve complete control over either the number or nature of arrivals; recently, an increasing number of countries are turning to policies to selectively admit highly-skilled workers. Other policies can also influence inflows or outflows indirectly. The question naturally arises as to how effective are these policies and what are their fiscal costs and benefits. This Section looks at a number of these issues.

\section{Border issues}

It is hard to find a convenient classification for immigration policies across OECD countries, since they are strongly influenced by each country's historical and geographical particularities. Table 6 suggests a possible classification, distinguishing countries where immigration has been an integral part of economic development for many years from those, mainly European, countries where the situation is more mixed, and those such as Japan and Korea where immigration has not traditionally been important at all. In most countries, policies seek to control total flows or their composition, or both; concern over how to retain natives, particularly the highly educated, who may wish to emigrate is also high on the agenda in many countries. ${ }^{17}$ Immigration controls generally allow a number of different immigration streams, for which entry conditions may vary. Broadly speaking these distinguish three broad motivations for immigration: family, humanitarian (e.g., refugees and asylum seekers) and economic motives.

The effectiveness of border measures cannot easily be assessed against a measure of what would happen without them. On the face of it, however, legal restrictions appear to be ineffective in many countries, since flows of illegal migration are very large compared with the legal flows. Illegal migration may be less costly than legal migration as far as public finance is concerned, since eligibility for welfare and other benefits is lower, but income and payroll tax revenues will also be lower. Other economic effects from immigration are likely to be similar in the case of illegal and legal immigrants (for given skill levels). The concept of maximising the economic benefit from immigration is not easy to apply, but if overall (legal) numbers are limited, it may well imply focusing on the highly skilled since net tax revenues are likely to be higher while costs (including social or congestion costs) per capita may be lower, or at least no higher than for the low-skilled. In practice, non-economic objectives may well overrule such economic arguments.

17. In many countries (effectively the whole of the EU, for example) immigration policies effectively assume that the supply of potential immigrants of all sorts exceeds the capacity of the country to absorb it, with the frequent exception of highly-skilled immigrants. Australia, Canada and New Zealand still feel that their population is lower than is desirable, though there does not appear to be an explicit target of some optimal level of population. 


\section{Attracting, or retaining, highly-skilled workers}

The idea that immigration of the highly-skilled should be a priority is becoming commonplace. This may be because their integration costs per capita are thought to be low and their contribution to economic output and the budget high; or more subtle effects may emerge, such as the benefits from clusters of research and development oriented activities and people. ${ }^{18}$ Most OECD countries have recently amended their legislation in order to facilitate the admission of foreign specialists. Measures include the relaxation of quantitative constraints, the setting up of special programmes for so-called "shortage occupations", the relaxation of criteria and procedures for entry of highly skilled workers and the reduction in requirements for foreign students to change their status if they wish to enter the labour market.

At the same time, many countries - especially developing countries - are concerned about a "brain drain" from the emigration of the highly skilled. If there are indeed significant cluster or scale effects, this concern is justified; facilitating the circulation of highly-skilled workers across frontiers while generating benefits for both sending and receiving countries may be difficult. While sending countries may view the depletion of their domestic pool of skills and the lost public investment in human capital as welfare losses, those that create opportunities for research, innovation and entrepreneurship at home are more likely to benefit from return flows of migrants, capital and access to international innovation networks.

Return flows of migrants, whether they were originally thought of as a brain drain or not, may well augment the stock of human capital if migrants return with knowledge or skills they would not have acquired without having emigrated. ${ }^{19}$

\section{Tax and benefit policies}

Just as the budgetary impact is important for assessing the costs and benefits of immigration, so tax and benefit structures (as well as public expenditure more generally) might influence the volume and nature of migration flows.

Theoretically, potential migrants may take into account welfare entitlements in destination countries when deciding whether and where to migrate. Even if for most migrants it is earnings in employment that matter, self-selection may lead migrants for whom welfare entitlements might be important - who would be those whose labour market position will be weak - to look for countries with generous welfare systems. Similarly, high-taxation countries may repel potential highly-skilled immigrants, although high levels of public infrastructure provision may partially offset this. Thus, caricaturising somewhat, high tax and spending countries may attract immigrants who tend to undermine their financial viability. ${ }^{20}$

18. A comprehensive discussion of many of the issues can be found in OECD (2002) and a shorter discussion in OECD Employment Outlook 2001, chapter 5.

19. There is in addition an argument that the possibility of being able to emigrate under a high-skill programme such as the H1-B visa programme in the United States may in fact augment the stock of human capital in an origin country (Mountford, 1997). The logic of the argument is that the potential wage premium for an emigrant is such that many potential emigrants seek to acquire the human capital (essentially a university degree in the right discipline) necessary to meet the requirements of such programmes. The argument relies on the numbers seeking to do this exceeding the number of places actually available in host countries by a sufficient amount. This may not be entirely plausible but at least makes the point that a simple accounting approach to emigration flows is not sufficient to show that it creates a brain drain.

20. For an extreme view, see Sinn (2002) where it is argued that increased international capital and labour mobility will lead to competition between tax and welfare systems in different countries which will in the 
It is unclear how strong an influence tax and benefit policies exert on the decision to migrate. One study of migrants from Egypt, Ghana, Morocco, Senegal and Turkey assessed the proportion of migrants who had information about labour market prospects or welfare provision prior to migration (Eurostat, 2001). Those who knew about labour market prospects were between twice and five times as numerous as those knowing about welfare (where the proportion ranged from under 10 per cent to as much as 25 per cent of migrants), which might suggest some influence from the latter, but could equally be entirely unrelated. Reducing any potential welfare-related incentive by adopting origin-based eligibility criteria for some benefits or facilities may be difficult. ${ }^{21}$ Some countries ${ }^{22}$ limit access to some types of welfare payment for immigrants until they have been resident for a certain period.

It may also be noted that high replacement rates in potential emigration countries may reduce the incentive to emigrate. The steep decline in Spanish emigration in the late 1960s and into the 1970s followed the introduction of social security in the 1960s, where there had been none before.

Some countries practice discrimination in favour of (some types of) immigrants in taxation policy. An example is the lower tax rates which apply to high-skilled immigrants in Denmark, for their first three years of residence. This may be justified by the probability that short-term, highly-paid migrants place little burden on public expenditures; it may also be a sign of high taxation on nationals.

A related problem considering the costs of emigration occurs in education finance. When the highlyeducated emigrate, especially if they emigrate when young, the social returns on the public funds spent on their education, and which can justify subsidised education, are enjoyed by the host country rather than the origin country. One approach to this which retains the advantages of subsidising provision is to provide some or all tertiary education finance in the form of loans repayable on emigration. ${ }^{23}$

The pension situation of emigrants can be important. Accrued public pension rights that cannot be incorporated into other countries' public systems, or only at a loss, will inhibit mobility although the public finances of emigration countries may thereby benefit. Although labour mobility generally enhances overall efficiency, individual states may have a financial interest in using pensions to inhibit emigration, a crude compensation for the difficulties in clawing back other public expenditures such as that on education mentioned above. Conversely, systems that compensate for lack of pension transferability by providing for cash payouts for emigrants need to be calculated carefully, to be fair while avoiding encouraging return migration of retirees at a cost that would exceed that of paying their pension in the host country. ${ }^{24}$

Portability issues are relevant for some other social payments, as well as health care. In the European Union, many of these barriers to migration have been reduced, although the situation is not uniform. The proportion of social benefits, excluding health, that are exportable is about 90 per cent of social

end erode the more generous systems. This may be thought of as a variant of the argument that strong labour and capital mobility in a monetary union leads automatically to fiscal policy harmonisation.

21. Proposals for such an approach exist, however. See Richter (2002), Sinn (2002 a), Sinn (2002 b) and the Scientific Council at the German Ministry of Finance (Wissenschaftlicher Beirat (2002)).

22. The United States, Australia and Denmark, for example.

23. See OECD (2001a), Vossersteyn and Canton (2001). Another approach (that exists in Singapore, Malaysia and Thailand, for example) is to attach a condition to student loans that the beneficiary return to the country of origin for a certain number of years; a guarantor is required to post a bond in case of default by the beneficiary.

24. As reportedly is the case for immigrants in Italy returning to their country of origin for retirement. See Moscarola (2001). 
expenditures in Italy and Spain while the proportion is closer to 70 per cent in France, Germany and Finland.

\subsection{Policies affecting the economic impact of migration}

\section{Labour market policies}

Many labour market measures have aims related to promoting equity and stability, with side-effects that may impede the functioning of the labour market to a greater or lesser extent. If immigrants are affected differently from nationals by these measures, whether simply by virtue of being immigrants or because their skill or age characteristics differ from nationals, the economic benefits from immigration may be affected, and the fact of immigration may call for a re-evaluation of the measures themselves. The relatively high unemployment among immigrants in most countries might suggest that labour markets function less well for immigrants than for natives, but this may be due more to immigrants having labour market characteristics that render them relatively vulnerable to unemployment than to an inherent effect from immigrant status. In either case, relatively higher unemployment rates among immigrants point to the importance of improving the ability of labour market institutions to absorb these kind of workers.

\section{Minimum wages}

While intended as protection against excessively low wages, minimum wage legislation tends to make it more difficult for low-skilled workers to get work. Since, in most countries, the foreign population has a lower average level of educational attainment than nationals, minimum wages in those countries may have a disproportionate impact on the employment prospects of immigrants and may be part of the explanation for the differential in unemployment rates observed.

Where the minimum wage is perhaps already too high, it is very likely to be causing unemployment among low-skilled immigrants. If immigrants are a large proportion of the vulnerable workforce - for example, where there is a high proportion of low-skilled among them, the social problems that unemployment creates in any group may be accentuated by the barrier to integration that this can represent; the case for inwork benefits as an alternative or supplement to minimum wages and/or the case for payroll tax cuts targeted to low-wage workers may be strengthened. ${ }^{25}$

\section{Employment protection legislation}

Employment protection legislation (EPL) is likely to slow labour market adjustment and tend to create an insider-outsider split in the labour market. ${ }^{26}$ Anything that slows labour market adjustment is likely to slow integration of immigrants, and immigrants are almost by definition outsiders. The links between EPL and labour market performance are not always clear cut, ${ }^{27}$ but where EPL is particularly strict ${ }^{28}$ and integration

25. Discussion of the impact of minimum wages on the labour market can be found in the OECD Employment Outlook, 1998, chapter 2.

26. EPL may cause higher labour costs, although the final effect depends on the wage bargaining process as trade unions may reduce wage claims in response to more labour protection (see Elmeskov et al,. (1998)).

27. See OECD Employment Outlook, 1999, chapter 2.

28. See the composite indicator of the strictness of EPL, OECD Employment Outlook, 1999, p.66. 
of immigrants appears to be slow, the question of such a link could be considered - might some weakening improve migrant integration without undermining the basic goals of the legislation? Models might be found in the increasing use of exemptions of temporary employment contracts from the full provisions of EPL in a number of countries.

Both EPL and minimum wage legislation may encourage illegal employment to avoid their constraints. Where EPL is strict and/or minimum wages high, the benefit from low-skilled immigrants will be low because of their poor employment prospects. A casual observation may suggest a link between illegal migration and formal labour markets that are unfriendly to the low-skilled: among the few countries where legal immigrants have an average education level at or exceeding that of natives are Greece, Spain and Italy (see Figure 2), countries in which there does tend to be a strong insider-outsider distinction in many parts of the labour market; these are all countries with high numbers of unskilled illegal immigrants working in low-paid jobs. ${ }^{29}$ This may be tolerated by the authorities (thereby implicitly encouraging illegal immigration) because it occurs frequently among natives, too.

Strong EPL is also thought to provide a "push" towards self-employment. This may be a contributory factor to the observation that in many countries immigrants are more inclined to be involved in entrepreneurial activity than natives.

\section{Active labour market policies}

As regards active labour market policies, the requirements of immigrants are likely to be more specialised than average, and the general OECD Jobs Study recommendation to avoid blanket approaches and try to concentrate on tailoring job-search support to individuals' needs is therefore particularly appropriate for this group. Improving language skills is the most obvious specific intervention that might be useful, since language barriers are widely recognised as the most important single factor limiting labour market integration of immigrants (for given skill levels). ${ }^{30}$ Making language skills part of the entry requirement would be more cost-effective than subsequent training. Both may in fact be useful, but if neither is implemented, labour market integration is likely to be poor for many immigrants. Although not immediately relevant for labour market policy, language training for children and spouses of immigrants should probably be a priority under any circumstances, to foster their integration into the host society as well as improve their future labour market prospects.

Competition in the labour market -- recognition of qualifications

Lack of comparability and reciprocal recognition of academic and professional qualifications to pursue a professional activity limit the degree of geographical mobility and reduce labour market integration. In the European Union, for example, diploma recognition in the public sector has not been achieved to the same extent or pace as in the private sector and access to public sector employment by nationals of other EU States is limited. Such barriers, including restricted recognition of foreign qualifications, are often claimed to be justified by the need to "maintain quality." While these claims may not be unfounded, the natural

29. This is not compelling evidence. Figure 2 does not control for the age distribution of the two populations: older nationals in those countries are likely to have had many fewer years of education than those of ages comparable with the immigrant population. And the United States is an example of a country with much illegal immigration but little stringent labour market legislation or generous welfare availability.

30 . There is a considerable literature on this. Recent examples are Shield and Wheatley Price (2001), Chiswick and Miller (2002). 
tendency of professional associations to restrict entry may have significant costs - for example in higher medical or legal costs - if the services of immigrants are being unjustifiably excluded.

\section{Product and other market policies}

\section{Barriers to entrepreneurship}

Barriers to entrepreneurship - unnecessary licensing and permitting requirements, administrative burdens, communications and procedural rules, etc., ${ }^{31}$ - may be relevant to more than just the highly-skilled (Figure 6). Migrants are often more entrepreneurial than average and can be a useful stimulus to entrepreneurial activity in host countries, and through network effects can act to facilitate the integration of subsequent migrants. In many cases, self-selection may be the explanation for the degree of entrepreneurial aptitude of migrants, ${ }^{32}$ but, whether or not this is the case, barriers to its exercise may prevent the full use of its potential. Just as in the case of entry barriers to professions mentioned earlier, some barriers to entrepreneurial activity may have justification, for example in health and safety legislation, but these do not justify many common restrictions.

The supply of capital can often be seen as a barrier to entrepreneurship. Just as native start-ups may suffer from a lack of credit history or collateral assets, immigrants are likely to find it even harder to raise finance (unless through immigrant financial networks, that often arise after some time precisely because of these initial barriers). And equally, just as it is difficult to see how to overcome barriers that are typically seen by potential lenders as mere prudence, it is hard to see what practical steps can be taken to improve matters. A potentially related, if controversial, policy measure is the financing for minorities scheme in the United States, where banks are required to make a certain proportion of new loans to borrowers from minority (but not immigrant, as such) communities.

\section{Fiscal policy issues}

Fiscal policy influences the economic impact of migration through its effects on labour market incentives and through links between migration and budget balances. These are not independent, since a key factor for the short-term budgetary impact of migrants is their experience in the labour market. As for the longer term budgetary impact, the nature of the public pension system can be an important factor.

\section{Incentives}

Apart from any possible role in influencing migration flows (see above), taxes and transfers can affect labour market incentives, for both residents and immigrants. The disincentive effect of high taxes on labour on the low paid is increased where means-tested transfers (such as for housing, health, disability etc.,) which result in high withdrawal rates as incomes increase - are an important part of the welfare system. Among low-skilled immigrants these effects may be particularly important (although where immigrants have reduced entitlement to such social assistance, their incentive to work is stronger than that of natives). Disincentive effects are particularly important for second earners in households, and might be expected to

31. See Nicoletti, Scarpetta and Boylaud (1999).

32. It may also be that this is a reaction to the difficulties of integrating into the labour market as an employee. 
reduce female participation rates. Female participation rates do tend to be lower among immigrants than among natives ${ }^{33}$, more often than is the case for male participation.

\section{Long-term budgetary impact}

The tax and transfer system also affects the impact of migration on public finance: as mentioned above, employed immigrants can have a significant beneficial effect. One important source of this benefit concerns pension contributions. It is now well-understood that feasible migration flows are no solution in themselves to the problem of population ageing, despite the favourable age-structure of current inflows of immigrants. The revenue that employed immigrants provide to public pension schemes nevertheless provides a useful, if small and temporary, smoothing effect to the financing problem coming in most countries. To ensure that this short-term improvement is not at the cost of a longer term deterioration in public finances, public pension provision for immigrants should be no better than actuarially fair (i.e., the present value of expected pension liabilities should be no more than the present value of expected contributions $^{34}$ ).

Pension reform is controversial in many countries and although progress has been made, this condition may not yet be satisfied. In practice, it can be very difficult to separate pension accounts from general government taxation and expenditure since pensions may be partly financed from general taxes, which immigrants also pay. According to the studies reported in Table 5, it appears to be generally the case that the present value of immigrants taxes and contributions exceeds, on average, the present value of their receipts from government, pensions included.

33. Their fertility rates are also typically higher than those of natives, which would tend to reduce participation rate. The extent to which they diverge from the participation rate of host-country native females is quite highly correlated with participation rates in their countries of origin.

34. A relative improvement, i.e,. in terms of implicit pension debt per capita or per unit of GDP, could be achieved with a less stringent condition. 
Table 6. Main migration systems and policy impact in OECD countries

\begin{tabular}{|c|c|c|c|}
\hline Type of system & $\begin{array}{l}\text { Settlement or } \\
\text { establishment model }\end{array}$ & $\begin{array}{l}\text { Mixed model of long-term } \\
\text { establishment }\end{array}$ & Labour migration model \\
\hline Examples & $\begin{array}{l}\text { Australia, Canada, New } \\
\text { Zealand, United States }\end{array}$ & $\begin{array}{l}\text { Belgium, France, Netherlands, } \\
\text { Sweden }\end{array}$ & Japan and Korea \\
\hline $\begin{array}{l}\text { Degree of } \\
\text { openness to the } \\
\text { various categories } \\
\text { of migrants }\end{array}$ & Highly open & $\begin{array}{l}\text { Effectively open under certain } \\
\text { conditions }\end{array}$ & Not very open \\
\hline $\begin{array}{l}\text { Selective } \\
\text { admission }\end{array}$ & $\begin{array}{l}\text { Stated ex ante } \\
\text { Strict }\end{array}$ & $\begin{array}{l}\text { Stated ex post } \\
\text { Medium or slight }\end{array}$ & $\begin{array}{l}\text { Stated ex post or ex ante } \\
\text { Strict }\end{array}$ \\
\hline $\begin{array}{l}\text { Dominant mode of } \\
\text { control }\end{array}$ & On admission & $\begin{array}{l}\text { Recurrent control (mainly } \\
\text { through issue and renewal of } \\
\text { residence permits) }\end{array}$ & $\begin{array}{l}\text { Mixed control on admission } \\
\text { and through renewal or not of } \\
\text { residence permits }\end{array}$ \\
\hline \multirow[t]{5}{*}{ Labour policies } & $\begin{array}{l}\text { Not predominant but } \\
\text { increasingly important }\end{array}$ & Strict & Very strict \\
\hline & $\begin{array}{l}\text { Self-allocation of migrants on } \\
\text { labour market }\end{array}$ & $\begin{array}{l}\text { Limited self-allocation of } \\
\text { migrants on the labour market }\end{array}$ & Specific allocation \\
\hline & $\begin{array}{l}\text { Employment situation generally } \\
\text { not an obstacle }\end{array}$ & $\begin{array}{l}\text { Employment situation may be } \\
\text { an obstacle }\end{array}$ & $\begin{array}{l}\text { Employment situation may be } \\
\text { an obstacle }\end{array}$ \\
\hline & Single permanent card & Multiple work permits & Multiple work permits \\
\hline & $\begin{array}{l}\text { Mobility possible, immediately } \\
\text { or in the short term }\end{array}$ & $\begin{array}{l}\text { Progressive removal (for some } \\
\text { categories) of mobility } \\
\text { constraints }\end{array}$ & $\begin{array}{l}\text { Slow or discretionary removal } \\
\text { of mobility constraints }\end{array}$ \\
\hline \multirow[t]{3}{*}{ Integration } & $\begin{array}{l}\text { Projected and in some cases } \\
\text { organised from the outset }\end{array}$ & $\begin{array}{l}\text { Not explicitly provided for but } \\
\text { organised during residence }\end{array}$ & Not explicitly provided for \\
\hline & Multi-cultural model & Assimilationist model & Cohabitationist model \\
\hline & $\begin{array}{l}\text { Naturalisation possible after a } \\
\text { short period de residence }\end{array}$ & $\begin{array}{l}\text { Naturalisation facilitated (jus } \\
\text { soli and jus sanguinis) }\end{array}$ & $\begin{array}{l}\text { Naturalisation restricted (jus } \\
\text { sanguinis) }\end{array}$ \\
\hline Main advantage & Targeted migration policy & Flexible and can be reoriented & $\begin{array}{l}\text { Possible adjustment to } \\
\text { economic fluctuations }\end{array}$ \\
\hline \multirow[t]{3}{*}{$\begin{array}{l}\text { Limitations of } \\
\text { system }\end{array}$} & $\begin{array}{l}\text { Inertia linked to settlement } \\
\text { immigration }\end{array}$ & Drift towards settlement model & $\begin{array}{l}\text { Structural instability in the } \\
\text { long term }\end{array}$ \\
\hline & $\begin{array}{l}\text { Qualitative impact limited in } \\
\text { the short term, especially in the } \\
\text { family stream }\end{array}$ & Risk of formation of minorities & Formation of minorities \\
\hline & Limits to selectivity & $\begin{array}{l}\text { Greater market segmentation } \\
\text { when admission rates are low }\end{array}$ & $\begin{array}{l}\text { Greater market segmentation } \\
\text { when admission rates are low }\end{array}$ \\
\hline $\begin{array}{l}\text { Margin of } \\
\text { manoeuvre of } \\
\text { policies over the } \\
\text { migration system }\end{array}$ & $\begin{array}{l}\text { Medium } \\
\text { Importance of interest groups } \\
\text { and lobbies }\end{array}$ & $\begin{array}{l}\text { Strong at national and local } \\
\text { levels. Decision-making power } \\
\text { left to various administrative } \\
\text { levels }\end{array}$ & $\begin{array}{l}\text { Slight at national and local } \\
\text { levels }\end{array}$ \\
\hline
\end{tabular}




\section{ANNEX \\ OVERVIEW OF EXISTING EMPIRICAL STUDIES ON FISCAL EFFECTS OF IMMIGRATION}

\section{Australia}

The consultancy Access Economics maintains an accounting model which estimates the effect of immigrants on the budget through time. ${ }^{35}$ To our knowledge this is the only model which uses targeted longitudinal data (from the Longitudinal Survey of Immigrants to Australia - the LSIA ${ }^{36}$ ) on actual rather than assumed behaviour of immigrants on employment, incomes, social security take-up, pensions, and public education. The LSIA also has information on migrants' incomes, which are used for estimates of direct and (combined with the Household Expenditure Survey) indirect tax revenues.

The model distinguishes immigrants by the programme under which they were admitted: Family, Concessional, Business Skills, Independent, Humanitarian. Only the first and the last put any net burden on the Commonwealth budget, and only in the latter case does this impact last into the long term. The model results do not distinguish groups of migrants by origin, or by linguistic ability, although one might expect associated variations. Expenditure on unemployment benefit, for example, appears to be greater for immigrants, especially those from non-English-speaking backgrounds, than for natives (Nahid and Shamsuddin (2001)).

This kind of accounting model can provide great detail on the direct impact of migrants, but does not take into account their overall economic impact. An earlier Australian study (Bureau of Immigration Research (1992)) used an economy-wide model to consider immigration's effects on the budget. With the capital stock fixed in the short-term but adjusting in the longer term, wages initially fall (and there is increased unemployment) though other incomes increase by more as exports and output increase. In the short run, there are net costs to the budget, but in the longer run as the capital stock adjusts and wages recover, this is reversed.

There is no immigrant-specific Australian study using generational accounts. Ablett (1999) ignores differences in average payment and benefit level between migrants and non-migrants belonging to the same age/gender cohort, ${ }^{37}$ but shows that the age-distribution effect alone can be quite significant. Since young adults are disproportionately represented in immigrant groups, they have high lifetime net contributions, having have received all, or most, of their education in their home country. The long-term effect for the government budget remains positive, after considering government spending on the children of migrants who were born in Australia and thus, according to this study, immigration helps to reduce budgetary pressures due to population ageing.

35. See Access Economics (2001).

36. The first cohort in the LSIA are immigrants who arrived in Australia during 1993-95, who were interviewed 6, 18 and 42 months after arrival. A second cohort, of people arriving in 1999-2000, has had only the first interview. Sample size is about 5200 (not counting spouses or dependants) in the first cohort, about 3100 in the second. See the Australian Immigration department website, http://www.immi.gov.au/research/lsia

37. Ablett justifies this by reference to, e.g., Whiteford (1991) who finds no major differences in budgetary impacts between immigrants and natives of the same age-cohort after the settling-in period of new arrivals. 


\section{Germany}

Riphahn (1998) observes that, for individuals included in the German Socio-Economic Panel, there is a lower tendency for foreigners than natives to depend on social assistance payments. Fertig and Schmidt (2001) extend the analysis to look at the difference between $1^{\text {st }}$ and $2^{\text {nd }}$ generation immigrants. Using probit analysis on 1995 Mikrozensus data, their estimates imply that, conditional on family circumstances, age, sex, education and employment history, first generation immigrants tend to be less likely than natives to be dependent on social welfare payments; in the second generation this remains the case for most identified nationalities, but to a lesser degree -- the welfare dependence characteristics of children of immigrants appears to converge towards that of natives.

Fertig and Schmidt compare these findings with data on perceptions about the welfare dependence of immigrants, based on a 1996 public opinion survey, ${ }^{38}$ where a small majority of respondents agree with the statement that foreigners are a burden for the social security system. ${ }^{39}$ However, the authors' conclusion, which shows that public perceptions are "out of line" with reality, is misleading. Immigrants are more welfare-dependent than natives, but this is because they have lower education and skill levels, higher unemployment rates and, if old, are less likely to have adequate pension. Conditional on their situation, however, immigrants are less likely than natives to be a burden on welfare.

Sinn et al. (2001) provide a detailed analysis of all tax payments of immigrants to the general government, and benefits received in a base year (1997). ${ }^{40}$ The overall result is that immigrants are, on average, a net burden to the public purse, a burden that declines through time. While in the pension system contributions by immigrants are higher than benefits received, net fiscal costs arise in the unemployment insurance system as migrants' contributions are, on average, less than benefits received. However, the overall result depends more on allocating general government spending pro rate to immigrants; if instead economies of scale in the provision of public services would be assumed, the overall fiscal effect could be different. Bonin et al., (2000) and Bonin (2001) apply a generational accounting approach to study the long-term budgetary effects of immigration. Compared with natives, immigrants have, on average, a lower income and consumption and their risk of being unemployed is higher; hence they pay lower taxes and receive higher unemployment benefits and social assistance, but they also get lower pensions. According to these estimates, an average immigrant, over a whole lifetime, pays net taxes of around DM 120000 (present value), while a native pays lifetime net taxes of around DM 150000 . Despite this, the native population benefits from immigration for two reasons: First, immigrants usually enter in the earlier years of their working life and thus impose fewer educational costs. The second reason arises from the existing implicit debt in the current pension system. In the logic of the generational accounting fiscal burden approach, future taxes have to be increased to eliminate this implicit government debt, having a higher number of immigrant tax payers alleviates the future additional burden for natives. Looking at the aggregate effects of immigrants, Bonin calculates the impact on the average tax rate required to maintain the government's inter-temporal budget constraint under varying assumptions about the rate of immigration. Against a baseline in which he calculates that a primary surplus of 6.1 per cent of GNP is needed in the absence of further net immigration, an annual net inflow of 200000 immigrants would reduce this to 5.0 per cent, and sufficient immigration to maintain a constant population would reduce it still further to 4.3 per cent. The latter scenario would require an annual net inflow of 300000 immigrants until 2010 and 500000 to

38. The Allgemeine Bevölkerungsumfrage der Sozialwissenschaften.

39. 42 per cent express some degree of agreement, against 37 per cent who disagree; among native respondents the figures are 43 and 36 per cent respectively. About 21 per cent of both groups were indifferent.

40. Government spending which cannot be allocated directly to the various groups of the population (such as education services, general administration, military spending) is distributed on a per capita basis. 
600000 after 2010. This illustrates that further immigration helps to lower the burden of fiscal adjustment for the current population, but it cannot eliminate it.

\section{Italy}

Moscarola (2001) uses a generational accounting approach (but, again, with very little immigrant-specific information) to look at the consequences of immigration for pension and other benefits, as well as nonsocial-security transfer payments. The finding that the current stock of immigrants, assuming they stay in Italy for the rest of their lives, is beneficial -- in the sense that the future tax rate required to meet the government's inter-temporal budget constraint is reduced by their presence -- depends largely on the age structure of immigrants, in particular the fact that the current stock of immigrants has many fewer children, compared to the native population. Many immigrants return to their country of origin for their retirement, however, and the paper finds that, paradoxically, this reduces the positive effect of the immigrant on the budget. This is because re-emigrants are entitled to take a cash payment in lieu of their pension entitlements, a benefit which appears to be better than actuarially fair. The exclusion of consideration of illegal migrants, though potentially important in the case of Italy, is probably unavoidable.

\section{Sweden}

Storesletten (1997) also uses a generational accounting approach for Sweden, computing the net present value of future taxes transfers and public expenditure due to new immigrants, by gender and by age at time of immigration. The author notes that looking at future net payments requires heroic assumptions about future earnings, fertility and return migration, necessitating a cautious approach to the numerical results, which could best be interpreted as a tool to help determine which factors matter for the net fiscal effect of immigrants. Johansson (2001) applies a similar methodology to emigrants from Sweden.

\section{United States}

Using data from the 1976 Survey of Income and Education, Blau (1984) finds a considerably higher average amount of welfare and social security payments transfers to immigrants than to natives. As in Fertig and Schmidt's results for Germany, this difference is caused by different family characteristics of transfer recipients, in particular (in this case) the higher average age of the immigrant population, and does not take into account their lifetime contributions, nor those of their American-born children, to public budgets.

Jensen (1989) compares poverty and public assistance payments between immigrants and natives, finding only a small difference, refuting the popular view that "most immigrants wind up on welfare. "Immigrants with over five years in the United States were significantly less likely to receive public assistance income than otherwise comparable natives. An interesting result is that the higher welfare receipts of immigrants results from their living in states with higher welfare benefits (and better economic conditions), such as California and New York.

Storesletten (2000) considers whether future patterns of migration can be found that will satisfy the government's inter-temporal budget constraint without an increase in the tax rate, using a CGE overlapping-generations model. Calibrated on existing immigration patterns, he finds that an increase in the tax on labour and capital income from 28.2 per cent to 32.6 per cent respectively (maintaining a payroll tax of 15.3 per cent as the only other source of government income) is necessary to eliminate the fiscal imbalance. This can be avoided by increasing the immigration rate by around 50 per cent, provided all future immigrants are selected by age and skill. No increase in low-skill immigration alone, however large, 
could avoid a tax increase. If immigrants could be selected by skill rather than by age, the rate of immigration would need to increase by around 80 per cent, although the number of highly-skilled immigrants would be multiplied seven-fold. Storesletten (2000) also calculates the present discounted value to the budget of an additional migrant.

Auerbach and Oreopoulos (1999) compare further immigration as it is assumed in population projections (baseline immigration), with a hypothetical scenario of no further immigration and calculating the fiscal impact in a generational accounting framework. Population projections and tax and transfer profiles are disaggregated by age groups, sex and distinguishes $1^{\text {st }}$ generation, $2^{\text {nd }}$ generation and natives (all others). The baseline scenario shows that tax increases and/or cuts in spending are needed to restore fiscal sustainability. Immigration, however, helps to restore the fiscal imbalance, thus alleviating the burden of adjustment borne by the existing.

The results depend, however, on how the costs of eliminating the fiscal imbalance are distributed over time and generations. The longer these measures are postponed, the higher the contribution of migrants and the lower the burden for the native population. The reason is that the share of new immigrants in the total population increases over time, so that more of them will be available to restore the imbalance which is implicit in current fiscal policies. But, if taxes would be raised immediately, or benefits cut, on all generations from the base year onward until the fiscal imbalance is eliminated, future generations (i.e., all the people born after the base year) would be somewhat better off without additional immigration. This is because with immediate policy action more of the burden is being placed on currently living generations. As the weight of new immigrants is lower on these rather than future generations, their contribution to restore the fiscal balance will be lower than if future generations would have to bear all adjustment costs. With such an immediate fiscal adjustment, each additional immigrant's net contribution would be negative, i.e. their net taxes would be lower than the cost of government purchases associated with immigration. But, this result again assumes that there are no economies of scale in the consumption of government goods and services, so that without migration there could be proportionately lower public consumption. If, however, part of public consumption (defence, for example) cannot be reduced, despite the decreased population (with immigration) the first result could still hold, namely that additional migrants alleviate the fiscal stress of natives even if adjustment measures are taken immediately.

For further information and references, see also Gustman and Steinmeier (2000), Razin and Sadka (1999), Smith and Edmonston (1997), and Borjas and Hilton (1996).

\section{Canada}

Simmons and Buttrick (1987) developed a conceptual framework for analysing the effects of immigration on the Canadian budget. It includes direct costs of immigration as settlement programmes and use of general programmes and their potential interaction. For example, expenditure to integrate immigrants (by offering language and job training programmes) can be seen as an investment, which speeds the contribution of immigrants to the economy and to tax revenues, thus reducing demand for welfare. 


\section{REFERENCES}

ALTONJI, J. et CARD, D., 1991, "The Effects of Immigration on the Labor Market Outcomes of Lessskilled Natives," in Abowd and Freeman, Immigration, Trade and the Labor Market, National Bureau of Economic Research, Chicago University Press.

BAUER, Th. et al., "Assessment of Possible Migration Pressure and its Labour Market Impact Following EU Enlargement to Central and Eastern Europe". Report for the Department for Education and Employment, Bonn/London, 1999.

BOERI, T., Brücker, H. and others (2002): "The Impact of Eastern European Enlargement on Employment and Labour Markets in the EU".

BORJAS G., (1983), The substituability of black, hispanic and white labor, Economic Inquiry, Vol 21, Janvier, pp. 93-106.

BORJAS G., (1986), The sensitivity of Labor demand functions to the choice of the dependent variable, Review of Economics and Statistics, n ${ }^{\circ} 68$, pp. 56-66.

BORJAS G., FREEMAN R. and KATZ L, (1996), "Searching for the Effect of Immigration on the Labor Market," NBER Working Paper Series n5454.

BORJAS, G.J. (1986), "The Self-employment Experience of Immigrants," The Journal of Human Resources, vol. $21, \mathrm{n}^{\circ} 4$.

BORJAS, G.J. (1987), "Self-selection and the Earnings of Immigrants," The American Economic Review, vol. $77, \mathrm{n}^{\circ} 4$.

BORJAS, G. (1999), "The Economic Analysis of Immigration" in: O. Aschenleifer and D. Card (eds), Handbook of Labour Economics, Vol. 3, Elsevier, 1999.

BORJAS, G. (2001), "Does immigration grease the wheels of the labour market?" Harvard University, mimeo.

BORGAS, G.J. (2002), “The Labor Demand Curve is Downward Sloping: Reexamining the Impact of Immigration on the Labor Market", Paper presented at the Conference of the European Association of Labour Economists, Paris, 2002.

BREUSS, F. (2001) "Macroeconomic Effects of EU Enlargement for Old and New Members", WIFO Working Papers, No. 143, April 2001.

BREUSS, F., (2001), "Macroeconomic Effects of EU Enlargement for Old and New Members", WIFO Working Papers, Nr. 143.

BUTCHER K. and Card D. (1991), "Immigration and Wages: Evidence from the 1980's", AEA Papers and proceedings, Vol $81 \mathrm{n}^{\circ} 2$.

BUTCHER, K.F and J. DINARDO (1998), "The immigrant and native-born wage distributions: evidence from United States censuses", NBER Working Paper no. 6630.

CAMAROTA S. (1998), "The Effects on the Low-Skilled Labor Market," Center for Immigration Studies, Center Paper 12.

CAMAROTA S., 1998, "The Effects on the Low-Skilled Labor Market," Center for Immigration Studies, Center Paper 12, Washington D.C.

CARD, D. (1990), "The Impact of the Mariel Boatlift on the Miami Labor Market," Industrial and Labor Relations Review, vol. 43, $\mathrm{n}^{\circ} 2$. 
CARRINGTON, W. et DELIMA, J.F. (1996), "The Impact of 1970s Repatriates from Africa on the Portuguese Labour Market," Industrial and Labor Relations Review, vol. 49, n 2.

CHISWICK B., CHISWICK C. and MILLER P., (1985), Are immigrants and natives perfect substitutes in production, International Migration Review, Vol $19 \mathrm{n}^{\circ} 4$.

COGNEAU, D. and Tapinos, G. (1995) "Libre -échange, répartition du revenus et migrations au Maroc", Revue d'Economie du développement $\mathrm{N}^{\circ} 1$.

COGNEAU, D., Dumont, J.C. and Izzo, P. (1998) "Intégration régionale, investissements directs et migrations dans l'espace euro-méditerranéeen : enseignements d'un modèle d'équilibre général calculable", OCDE, Migrations, Libre-Echange et Intégration Régionale dans le Bassin Méditerranéen.

COPPEL, J., J-C Dumont and I. Visco (2001), "Trends in immigration and economic consequences", OECD Economics Department Working Paper No.284.

DANG, T., P. Antolin and H. Oxley (2001), "Fiscal implications of ageing: projections of age-related spending", OECD Economics Department Working Paper No.305.

DE NEW J. and ZIMMERMANN K. (1993), "Native Wage Impacts of Foreign Labour: a random effects panel analysis", CEPR, Discussion Paper n ${ }^{\circ} 851$.

DIAZ-EMPARANZA, I. et ESPINOSA, A., (2000) "Análisis de la Relación entre la Immigración Internacional y el Desempleo", mimeo.

DIMA (1999), "Population Flows: Immigration Aspects", Department of Immigration and Multicultural Affairs, Canberra.

DOLADO J., JIMENO J. and DUCE R., (1996), "The effects of Migration on the Relative Demand of Skilled versus Unskilled Labour: evidence from Spain", CEPR, Discussion Paper n ${ }^{\circ} 1476$.

ELMESKOV, J, J. Martin and S. Scarpetta (1998), "Key lessons for labour market reforms: evidence from OECD countries' experiences", Swedish Economic Policy Review, vol.5 no.2, pp.205-252.

EUROSTAT (2001) "Pourquoi les individus migrent-ils?" Statistiques en bref, theme 3 -- 1/2001.

FAINI, R.J. and Venturini, A. (1993) "Trade, Aid and Migration : Some basic Policy issues", European Economic Review, Vol.37, pp.435-442.

GANG I. and RIVIERA-BATIZ F. (1994), "Labor Market Effects of Immigration in the United States and Europe," Journal of Population Economics, $\mathrm{n}^{\circ} 7$.

GARSON, J.P., MOULIER-BOUTANG, Y., SILBERMAN, R. et MAGNAC, T. (1987), "La Substitution des Autochtones aux Etrangers sur le Marché du Travail dans la CEE," Commission des Communautés européennes et GRAMI, Paris.

GEARY P. and O'GRADA C. (1985), "Immigration and the Real Wage Time Series Evidence from the United States, 1820-1977", Centre for Economic Policy Research, Discussion Paper n` 71.

GROSS, D. (2000), "Three Million Foreigners, Three Million Unemployed? Immigration and the French Labor Market", International Monetary Fund working paper 99/124.

GrossMAN JB., (1982), The substituability of natives and migrants in production, Review of Economics and Statistics, 64, pp. 596-603.

HATTON, T. J. and J. G. Williamson (1998), "The Age of Mass Migration: causes and economic consequences," OUP.

HATTON, T. J. and J. G. Williamson (2002), "What Fundamentals Drive World Migration?", NBER Working Paper Series, No.9159. 
HICKS, J. R. (1932), "A Theory of Wages", MacMillan, New York.

HILLE, H. and Straubhaar, T.(2001) "The Impact of EU Enlargement on Migration Movements and Economic Integration: Results of Recent Studies, in Migration Policies and EU Enlargement", Paris, OECD, 2001.

HUNT, J. (1992), "The Impact of the 1962 Repatriates From Algeria on the French Labor market," Industrial and Labor Relations Review, vol. 45, ${ }^{\circ} 3$.

JAYET H. et RAJAONARISON D. (2001), "Les Immigrants et le Marché du travail. Une mesure des effets sur les rémunérations et l'emploi", Miméo

JENSEN, L. (1989) "The New Immigration: Implications for Poverty and Public Assistance Utilization", Greeenwood Press, New York.

LALONDE, R.J. et TOPEL, R.H. (1992), "The Assimilation of Immigrants in the U.S. Labour Market", $n$ G.J. Borjas et R.B. Freeman (dir. pub.) Immigration, Trade and the Labour Market, University of Chicago Press, Chicago.

MARGO R., (1997), Wages in California During the Gold Rush, NBER Working Paper No.h0101.

MARR W. et SIKLOS, P. (1994), "The Link Between Immigration and Unemployment in Canada," Journal of Policy Modeling, vol. 16, $\mathrm{n}^{\circ} 1$.

MOLLE, W. (1994) "The Economics of European Integration: Theory, practice, Policy", Aldershot, Darmouth Publishing Company, Chapter 9.

MOSCAROLA, F. C. (2001) "The effects of immigration inflows on the sustainability of the Italian welfare state", Center for Research on Pensions and Welfare Policies, Working Paper no. 6/01, Turin.

MOUHOUD, E.M. (1998) "Investissements directs étrangers, migrations et intégration régionale", OECD, Migration and Development : New Partnerships for Co-operation.

MOUNTFORD A., 1997, "Can a Brain Drain Be Good for Growth in the Source Economy?", Journal of Development Economics, Vol 53

MUHLEISEN, M. et ZIMMERMANN, K. (1994), "A Panel Analysis of Job Changes and Unemployment", European Economic Review, n 38.

MULLER, T. et ESPENSHADE, T. (1985), "The Fourth Wave: California Newest Immigrants", Urban Institute Press, Washington.

MUNDELL, R.A. (1957) «International Trade and Factor Mobility, American Economic Review, Vol. 64, December.

NICOLETTI, G., S. Scarpetta and O. Boylaud (1999), "Summary indicators of product market regulation with an extension to employment protection legislation", OECD Economics Department Working Paper no. 226.

OECD (1994) Migration and Development : New Partnerships for Co-operation.

OECD (1997), "Implementing the OECD jobs strategy, Member countries' experience", Paris.

OECD (1998), Employment Outlook.

OECD (1998a) Migration and Regional Economic Integration in Asia.

OECD (1998b) Migration, Free Trade and Regional Integration in North America

OECD (1998c), "Migration, Free Trade and Regional Integration in the Mediterranean Basin ".

OECD (2000a), OECD Economic Outlook No. 68 
OECD (2000b), Globalisation, Migration and Development.

OECD (2001a), Trends in International Migration

OECD (2001b), OECD Economic Outlook, No. 70, Paris (Chapter 5, Investment in human capital through post-compulsory education and training)

OECD (2001c), OECD Employment Outlook, June, Paris.

OECD (2002) International mobility of the highly skilled

OECD/WIFO, (1997) Migration, Free Trade and Regional Integration in Central and Eastern Europe.

O’GRADA C. (1985) "On two aspects of post war Irish emigration" CEPR Discission Paper 52

PISCHKE JS. and VELLING J. (1994), "Wage and Employment Effects of the Immigration to Germany: an analysis based on local labour markets", CEPR, Discussion Paper n` 935.

POPE D. et WITHERS, G. (1993), "Do Migrants Rob Jobs ? Lessons of Australian History, 1861-1991", The Journal of Economic History, vol. 53, $\mathrm{n}^{\circ} 4$.

RAZIN, A., E. SADKA, and P. SWAGEL, (1998) "Tax Burden and Migration: A Political Economy Theory and Evidence", NBER Working Paper No.67

RAZIN, A. and E. SADKA (2000), "Interactions between international migration and the welfare state", CESifo WPS no.337.

RAZIN, A and E. SADKA (2000), "Unskilled Migration: a Burden or a Boon for the Welfare State," Scandinavian Journal of Economics, vol 102.

RICHARD, A. (1994) "Trade Liberalisation and Migration Flows", OECD, Migration and Development : New Partnerships for Co-operation.

RICHTER, W. F. (2002), "Delayed integration of mobile labor: a principle for coordinating taxation, social security, and social assistance", CESifo Working Paper No.624, December 2001.

SCHIFF, M (1994) "How Trade, Aid and Remittances Affect International Migration", World Bank Policy Research Paper $\mathrm{N}^{\circ} 1376$, November.

SHIELDS, M. A. and S. Wheatley Price (2001), "Language fluency and immigrant employment prospects: evidence from Britain's ethnic minorities," Applied Economics Letters vol. 8, pp. 741-745

SIMON, J., MOORE, S. et SULLIVAN, R. (1993), "The Effect of Immigration on Aggregate Native Unemployment: An Across-city Estimation," Journal of Labour Research, vol. XIV, n 3, été 1993.,

SINN, H.-W. (2001), "The Value of children and Immigrants in a Pay-as-you-go Pension System", ifo Studien 1/2001, pp.77-94.

SINN, H.-W. (2002 a), "The New Systems Competition", NBER Working Paper No.8747, January, 2002.

SINN, H.-W. (2002 b), "EU Enlargement and the Future of the Welfare State", Scottish Journal of Political Economy, Vol. 49, February 2001, No.1.

SINN, H.-W., G. Flaig, M. Werding, S. Munz, N. Dull, H. Hofmann, A. Hänlein, J. Kruse, H.-J. Reinhard and B. Schulte (2001): EU-Erweiterung und Arbeitskräftemigration, Wege zu einer schrittweisen Annäherung der Arbeitsmärkte, ifo Beiträge zur Wirtschaftsforschung.

SINN, H.-W., M. Werding (2001a), "Immigration and EU Eastern Enlargement", CESifo Forum, Summer 2001. 
STRAUBHAAR, T (1988) "International labour Migration within a Common Market: Some Aspects of EC experience", Journal of Common Market Studies, Vol. 27, Nº1, pp.44-62. Schiff, M (1994) "How Trade, Aid and Remittances Affect International Migration", World Bank Policy Research Paper $\mathrm{N}^{\circ} 1376$, November.

TAPINOS, G (1994) "Regional Economic Integration and its Effects on Employment and Migration", OECD, Migration and Development: New Partnerships for Co-operation.

UNITED NATIONS (2000),"Replacement Migration: Is a Solution to Declining and Ageing Populations?", Population Division, Department of Economics and Social Affairs, New York.

VOSSENSTEYN, H and E. Canton (2001), "Tuition fees and accessibility: the Australian HECS", in S. Uitgevers (ed.), Higher Education Reform: Getting the Incentive Right, The Hague.

WARREN, R. (1997), "Estimates of the Unauthorised Immigrant Population Residing in the United States: October 1996", Unpublished Document from the U.S. Immigration and Naturalisation Service, Office of Policy and Planning.

WEISS, A. and G. S. Epstein (2001), "A Theory of Immigration Amnesties" CEPR Discussion Paper no. 2830, June.

Wissenschaftlicher Beirat beim Bundesministerium der Finanzen (2002), Freizügigkeit und soziale Sicherung in Europa, Schriftenreihe des BMF, Heft 69, Stollfuß Verlag, Bonn.

WITHERS, G. and POPE, D. (1985), "Immigration and Unemployment," The Economic Record, n61, June. 


\title{
CESifo Working Paper Series
}

\author{
(for full list see www.cesifo.de)
}

809 Florian Englmaier and Achim Wambach, Contracts and Inequity Aversion, November 2002

810 Sarbajit Sengupta, Delegating Recruitment under Asymmetric Information, December 2002

811 Rajshri Jayaraman, On the Partial Public Provision of a Private Good, December 2002

812 Stéphanie Stolz, Banking Supervision in Integrated Financial Markets: Implications for the EU, December 2002

813 Christian Keuschnigg, Taxation of a Venture Capitalist with a Portfolio of Firms, December 2002

814 Inés Macho-Stadler and David Pérez-Castrillo, Settlement in Tax Evasion Prosecution, December 2002

815 Rainer Niemann and Dirk Simons, Costs, Benefits, and Tax-induced Distortions of Stock Option Plans, December 2002

816 Jan-Egbert Sturm and Barry Williams, Deregulation, Entry of Foreign Banks and Bank Efficiency in Australia, December 2002

817 V. Anton Muscatelli, Patrizio Tirelli, and Carmine Trecroci, Monetary and Fiscal Policy Interactions over the Cycle: Some Empirical Evidence, December 2002

818 Claude Hillinger, A General Theory of Price and Quantity Aggregation and Welfare Measurement, December 2002

819 Erkki Koskela and Ronnie Schöb, Optimal Capital Taxation in Economies with Unionised and Competitive Labour Markets, December 2002

820 Sheilagh Ogilvie, Guilds, Efficiency, and Social Capital: Evidence from German ProtoIndustry, December 2002

821 Hans Gersbach and Verena Liessem, Financing Democracy, December 2002

822 Costas Hadjiyiannis, Panos Hatzipanayotou, and Michael S. Michael, Optimal Tax Policies with Private-Public Clean-Up, Cross-Border Pollution and Capital Mobility, December 2002

823 François Ortalo-Magné and Sven Rady, Homeownership: Low Household Mobility, Volatile Housing Prices, High Income Dispersion, December 2002 
824 Syed M. Ahsan and Panagiotis Tsigaris, Measuring the Social Discount Rate under Uncertainty: A Methodology and Application, December 2002

825 Kai A. Konrad, Altruism and Envy in Contests: An Evolutionarily Stable Symbiosis, December 2002

826 Robert S. Chirinko and Huntley Schaller, A Revealed Preference Approach to Understanding Corporate Governance Problems: Evidence from Canada, December 2002

827 Geir B. Asheim, Green National Accounting for Welfare and Sustainability: A Taxonomy of Assumptions and Results, December 2002

828 Andrea Gebauer, Chang Woon Nam, and Rüdiger Parsche, Lessons of the 1999 Abolition of Intra-EU Duty Free Sales for Eastern European EU Candidates, December 2002

829 Giacomo Corneo, Work and Television, December 2002

830 Vivek H. Dehejia and Yiagadeesen Samy, Trade and Labour Standards - Theory, New Empirical Evidence, and Policy Implications, December 2002

831 Geir B. Asheim and Wolfgang Buchholz, A General Approach to Welfare Measurement through National Income Accounting, December 2002

832 Aaron Tornell and Frank Westermann, The Credit Channel in Middle Income Countries, January 2003

833 Gebhard Flaig, Time Series Properties of the German Monthly Production Index, January 2003

834 Campbell Leith and Jim Malley, Estimated Open Economy New Keynesian Phillips Curves for the G7, January 2003

835 Burkhard Heer and Bernd Süssmuth, Inflation and Wealth Distribution, January 2003

836 Erkki Koskela and Leopold von Thadden, Optimal Factor Taxation under Wage Bargaining - A Dynamic Perspective, January 2003

837 Carola Grün and Stephan Klasen, Growth, Income Distribution, and Well-Being: Comparisons across Space and Time, January 2003

838 Robert S. Chirinko and Ulf von Kalckreuth, On the German Monetary Transmission Mechanism: Interest Rate and Credit Channels for Investment Spending, January 2003

839 Sascha O. Becker, Andrea Ichino, and Giovanni Peri, How Large is the "Brain Drain" from Italy?", January 2003

840 Albert Berry and John Serieux, All About the Giants: Probing the Influences on Growth and Income Inequality at the End of the $20^{\text {th }}$ Century, January 2003 
841 Robert Fenge and Martin Werding, Ageing and the Tax Implied in Public Pension Schemes: Simulations for Selected OECD Countries, January 2003

842 Robert Fenge and Martin Werding, Ageing and Fiscal Imbalances Across Generations: Concepts of Measurement, January 2003

843 Giovanni Andrea Cornia, The Impact of Liberalisation and Globalisation on Income Inequality in Developing and Transitional Economies, January 2003

844 Peter Fredriksson and Per Johansson, Program Evaluation and Random Program Starts, January 2003

845 Bernd Hayo and Matthias Wrede, Fiscal Equalisation: Principles and an Application to the European Union, January 2003

846 Syed M. Ahsan and Jaideep Oberoi, Inequality, Well-being and Institutions in Latin America and the Caribbean, January 2003

847 Chang Woon Nam and Doina Maria Radulescu, The Role of Tax Depreciation for Investment Decisions: A Comparison of European Transition Countries, January 2003

848 V. Bhaskar and Steinar Holden, Wage Differentiation via Subsidised General Training, January 2003

849 Paloma Lopez-Garcia, Labour Market Performance and Start-up Costs: OECD Evidence, January 2003

850 Christian Keuschnigg and Soren Bo Nielsen, Public Policy for Start-up Entrepreneurship with Venture Capital and Bank Finance, January 2003

851 Yin-Wong Cheung, Menzie D. Chinn, and Eiji Fujii, China, Hong Kong, and Taiwan: A Quantitative Assessment of Real and Financial Integration, January 2003

852 Gregory D. Hess, The Economic Welfare Cost of Conflict: An Empirical Assessment, February 2003

853 Douglas J. Cumming and Jeffrey G. MacIntosh, Comparative Venture Capital Governance. Private versus Labour Sponsored Venture Capital Funds, February 2003

854 Eckhard Janeba and John Douglas Wilson, Decentralization and International Tax Competition, February 2003

855 Tapio Palokangas, Capital Accumulation and Employment Cycles in a Model of Creative Destruction, February 2003

856 Brendan Walsh, When Unemployment Disappears: Ireland in the 1990s, February 2003

857 Luis H. R. Alvarez and Erkki Koskela, A General Approach to the Stochastic Rotation Problem with Amenity Valuation, February 2003

858 Christian Schultz, Strategic Campaigns and Redistributive Politics, February 2003 
859 Ernst Fehr and Joseph Henrich, Is Strong Reciprocity a Maladaptation? On the Evolutionary Foundations of Human Altruism, February 2003

860 Haizhou Huang, Dalia Marin, and Chenggang Xu, Financial Crisis, Economic Recovery and Banking Development in Former Soviet Union Economies, February 2003

861 Pedro Cardoso and Bernard M.S. van Praag, How Sustainable Are Old-age Pensions in a Shrinking Population with Endogenous Labour Supply?, February 2003

862 Volker Meier, Efficient Transfer of Aging Provisions in Private Health Insurance, February 2003

863 Edward Castronova, Theory of the Avatar, February 2003

864 Robert S. Chirinko, Hans van Ees, Harry Garretsen, and Elmer Sterken, Investor Protections and Concentrated Ownership: Assessing Corporate Control Mechanisms in the Netherlands, February 2003

865 Bernard M.S. van Praag and Pedro Cardoso, The Mix Between Pay-as-you-go and Funded Pensions and what Demography has to do with it, February 2003

866 Ernst Fehr, Urs Fischbacher, Bernhard von Rosenbladt, Jürgen Schupp, and Gert G. Wagner, A Nation-Wide Laboratory. Examining Trust and Trustworthiness by Integrating Behavioral Experiments into Representative Survey, February 2003

867 Frank Heinemann, The Inflationary Impact of Wage Indexation, February 2003

868 Eytan Sheshinski, Bounded Rationality and Socially Optimal Limits on Choice in a Self-Selection Model, February 2003

869 M. Hashem Pesaran, Estimation and Inference in Large Heterogenous Panels with Cross Section Dependence, February 2003

870 Luis H. R. Alvarez and Erkki Koskela, On the Tree-Cutting Problem under Interest Rate and Forest Value Uncertainty, February 2003

871 Norbert Berthold and Rainer Fehn, Unemployment in Germany: Reasons and Remedies, February 2003

872 Clemens Fuest, Bernd Huber, and Philipp Tilleßen, Tax Policy and Entrepreneurship in the Presence of Asymmetric Information in Capital Markets, February 2003

873 Eytan Sheshinski, Optimum and Risk-Class Pricing of Annuities, February 2003

874 Willi Leibfritz, Paul O'Brien and Jean-Christophe Dumont, Effects of Immigration on Labour Markets and Government Budgets - An Overview, February 2003 